\title{
A scoping review of factors that influence opioid overdose prevention for justice- involved populations
}

\author{
Christine E. Grella ${ }^{1 *}$ D, Erika Ostlie ${ }^{2}$, Christy K. Scott ${ }^{1}$, Michael L. Dennis ${ }^{3}$, John Carnevale ${ }^{2}$ and Dennis P. Watson ${ }^{1}$
}

\begin{abstract}
Background: There is a high risk of death from opioid overdose following release from prison. Efforts to develop and implement overdose prevention programs for justice-involved populations have increased in recent years. An understanding of the gaps in knowledge on prevention interventions is needed to accelerate development, implementation, and dissemination of effective strategies.
\end{abstract}

Methods: A systematic search process identified 43 published papers addressing opioid overdose prevention in criminal justice settings or among justice-involved populations from 2010 to February 2020. Cross-cutting themes were identified, coded and qualitatively analyzed.

Results: Papers were coded into five categories: acceptability $(n=8)$, accessibility $(n=4)$, effectiveness $(n=5)$, feasibility $(n=7)$, and participant overdose risk ( $n=19)$. Common themes were: (1) Acceptability of naloxone is associated with injection drug use, overdose history, and perceived risk within the situational context; (2) Accessibility of naloxone is a function of the interface between corrections and community; (3) Evaluations of overdose prevention interventions are few, but generally show increases in knowledge or reductions in opioid overdose; (4) Coordinated efforts are needed to implement prevention interventions, address logistical challenges, and develop linkages between corrections and community providers; (5) Overdose is highest immediately following release from prison or jail, often preceded by service-system interactions, and associated with drug-use severity, injection use, and mental health disorders, as well as risks in the post-release environment.

Conclusion: Study findings can inform the development of overdose prevention interventions that target justiceinvolved individuals and policies to support their implementation across criminal justice and community-based service systems.

Keywords: Opioid overdose, Naloxone, Overdose prevention, Harm reduction, Criminal justice system

\section{Background}

One in four individuals with opioid use disorders (OUD) are involved with the criminal justice system during the course of a year [1], stemming from the debilitating effects of these disorders and the criminal behavior that often accompanies opioid use. Moreover, any level of

\footnotetext{
* Correspondence: cegrella@chestnut.org

${ }^{1}$ Chestnut Health Systems, 221 W. Walton St, Chicago, IL 60610, USA

Full list of author information is available at the end of the article
}

opioid use is associated with higher odds of criminal justice involvement, with increasing severity of opioid use, i.e., across stages from use to disorder, associated with greater risk of criminal justice system involvement [2]. When individuals with OUD are released from confinement, they face a heightened risk of opioid overdose, stemming from the loss of habituation and physical tolerance that occurs when opioid use is interrupted during a period of incarceration. Indeed, numerous studies have 
identified the high risk of opioid overdose in the period immediately following discharge from prison [3].

Given the dramatic evidence for the increased risk of overdose following prison release (as well as periods of confinement in jail), there is increasing attention toward developing effective strategies to prevent opioid overdose among justice-involved populations. Foremost is providing access to and training in use of naloxone, an opioid antagonist that reverses the effects of overdose. Use of naloxone for overdose reversal has gained increasing acceptance both among the medical community and general public, as well as receiving legislative support allowing for its distribution and use by lay persons [4]. Criminal justice systems have increasingly recognized the need to provide prevention training to their staff on naloxone use for overdose reversal, and several pilot programs have tested strategies for training staff, incarcerated individuals, and family members in its use. Take-home naloxone programs have also been developed that provide training to inmates and their family members on how to administer naloxone and naloxone kits have been provided to individuals at the time of their release to the community. Moreover, as individuals re-enter the community following release, they may also access naloxone through community-based providers, such as re-entry programs and syringe exchange programs [5-7].

Despite the urgent need to increase access to overdose prevention interventions for justice-involved populations, there is still limited understanding of the types of interventions that have been implemented across criminal justice and community settings, the challenges encountered in their implementation, and their outcomes. Moreover, a large body of research has developed on the risk of overdose among justiceinvolved individuals with OUD, and this literature can inform the development of interventions that target high-risk individuals and situations and/or take advantage of frequent points of contacts with this population.

\section{Study aim and rationale}

The aim of this study was to conduct a scoping review of the literature regarding factors that influence the development, implementation, and outcomes of overdose prevention interventions for justice-involved populations, including in both correctional and community settings. A scoping review utilizes the same search procedures as those used in systematic reviews but does not include a quantitative synthesis of data across studies. Instead, a scoping review is appropriate to assess a heterogeneous set of studies that use different methodological approaches to address a common theme [8]. A qualitative synthesis is used to assess the range of studies and nature of their findings, and to identify common themes, areas of concurrence, and research gaps.

This approach was considered appropriate to the current review given the range of studies that address this topic using diverse study designs, including both qualitative and quantitative studies; the diverse settings in which overdose prevention interventions may be implemented in the criminal justice system and community; and inclusion of studies addressing both implementation and outcomes of overdose prevention interventions. The present scoping review was guided by the following research questions:

1) What opioid overdose prevention interventions currently exist that are specifically designed for criminal justice-involved populations or are utilized by this population?

2) What factors influence the development, implementation, and use of opioid overdose interventions for criminal justice-involved populations, including participant and situational risk and protective factors for overdose?

3) What are outcomes of opioid overdose interventions for criminal justice-involved populations?

\section{Methods \\ Study design}

The review was informed by established methods for conducting and reporting systematic and scoping reviews, as articulated in the Preferred Reporting Items for Systematic Reviews and Meta-Analyses (PRISMA) guidelines $[9,10]$ and the PRISMA Extension for Scoping Reviews (PRISMA ScR) [8]. A qualitative synthesis was used to assess the nature and extent of the opioid overdose prevention literature as it pertains to criminal justice populations, research gaps, common themes, and intervention strategies.

\section{Eligibility criteria}

This review included peer-reviewed publications ${ }^{1}$ of studies conducted in the U.S. and other countries, although papers not published in English were excluded. The search was limited to studies published between January 2010 and February 2020. This window was selected as it corresponds with the period of the initial upsurge in opioid overdose deaths in the early 2000's [11], leading to the development of community-based

\footnotetext{
${ }^{1}$ At the same time, we conducted a search using the same criteria of "grey" (unpublished) literature and identified 7 program descriptions, handbooks, or implementation guides on opioid overdose programs related to justice-involved populations. Although these are outside of the scope of the present review, we provide the list of these documents in Supplemental Material to this paper as a resource.
} 
naloxone distribution programs $[5,6]$ and overdose prevention programs specifically for justice-involved populations [12]. Articles were excluded based on the following criteria:

- Not in English

- Published prior to 2010

- Not published in a peer-reviewed journal

- Does not sample a criminal justice population, or measure criminal justice involvement (current or past), or include as a variable in qualitative analyses

- Does not include "opioid overdose," "overdose prevention," or "harm reduction" either as a measure in descriptive analysis or a directly measured outcome

- Is a clinical trial protocol for which more recent outcome article was obtained

- Is not a study that either collected primary data or analyzed secondary data (e.g., systematic reviews, literature reviews, opinion pieces)

- Is a conference abstract

\section{Search strategy}

An electronic literature search of published papers was conducted of the following databases: PubMed, PsycInfo, and the National Criminal Justice Reference Service (NCJRS). Two reviewers worked on the search that was conducted the week of February 24, 2020. The lead project manager then reviewed all results across reviewers and provided feedback for consistency. Two sets of search terms were used: one set pertaining to overdose prevention and naloxone terms (11 terms) and one set pertaining to criminal justice terms (6 terms). Each of the overdose prevention terms were searched in combination with each of the criminal justice terms for a total of 66 search term pairs searched across each of the databases identified.

All initial search results were imported into Zotero and an Excel spreadsheet for review. Two reviewers used a four-tiered search and review process: 1) Search results were initially screened for duplication across databases and results were unduplicated; 2) all records were then screened for inclusion based on title and abstract; 3) full-text review based on inclusion criteria was then conducted on remaining articles; and 4) once the full-text review was completed, article reference lists were reviewed to determine if there were any additional articles that met inclusion criteria. Articles found in the reference lists were reviewed using steps 1-3 described above. See Fig. 1 for the Flow Chart of the search results, based on the PRISMA criteria [8]; the PRISMA checklist is in the Additional file 1 and sample search terms in Additional file 2.

\section{Information collected}

Two reviewers abstracted data on article and study characteristics and entered these into a centralized Excel database using the following parameters; 1) study identification, e.g., author[s], year of publication, full citation; 2) study characteristics, e.g., aim, research design, setting; 3) sample characteristics, e.g., socio-demographics, criminal justice status, opioid use history; 4) results, e.g. study findings on overdose rates, use of and access to naloxone, intervention outcomes, overdose risk factors and criminal justice involvement, and service-system contacts; and 5) study limitations. The abstraction review was concluded on February 29, 2020 and included articles published online prior to in-print publication at that time. Abstraction of articles found during the reference list review was completed on July 6, 2020.

\section{Selection of articles included in analysis}

Included studies specifically addressed participants in a criminal justice setting or justice-involved participants in community settings, history of prior criminal justice involvement, or examined influence of criminal justice status on study participants. Further, studies specifically addressed opioid overdose, either prevalence or risk of, or development, implementation, and outcomes of interventions that aim to reduce opioid overdose.

\section{Analysis}

The analysis for this paper uses 43 published papers that pertain to the topic of "opioid overdose prevention within criminal justice settings or for justice-involved populations." We first summarized the nature of the included studies by study location, type of correctional setting or population, study design, and relevance to the topic of opioid overdose. An inductive qualitative analysis was conducted [13] in which: 1) each paper was coded based on variables related to the study research questions on overdose prevention, 2) emergent themes were then classified into domains and studies were coded into these domains, and 3) comparative analyses were summarized both within and across domains. All codes and themes were reviewed among the study team and any discrepancies were discussed until consensus was achieved.

\section{Results}

Characteristics of included studies $(n=43)$

Study locations

United States $(n=20)$, United Kingdom (England, Scotland, Wales; $n=11)$, Australia $(n=6)$, Scandinavia (Sweden, Norway; $n=3)$, Canada $(n=2)$, Russia $(n=1)$. 


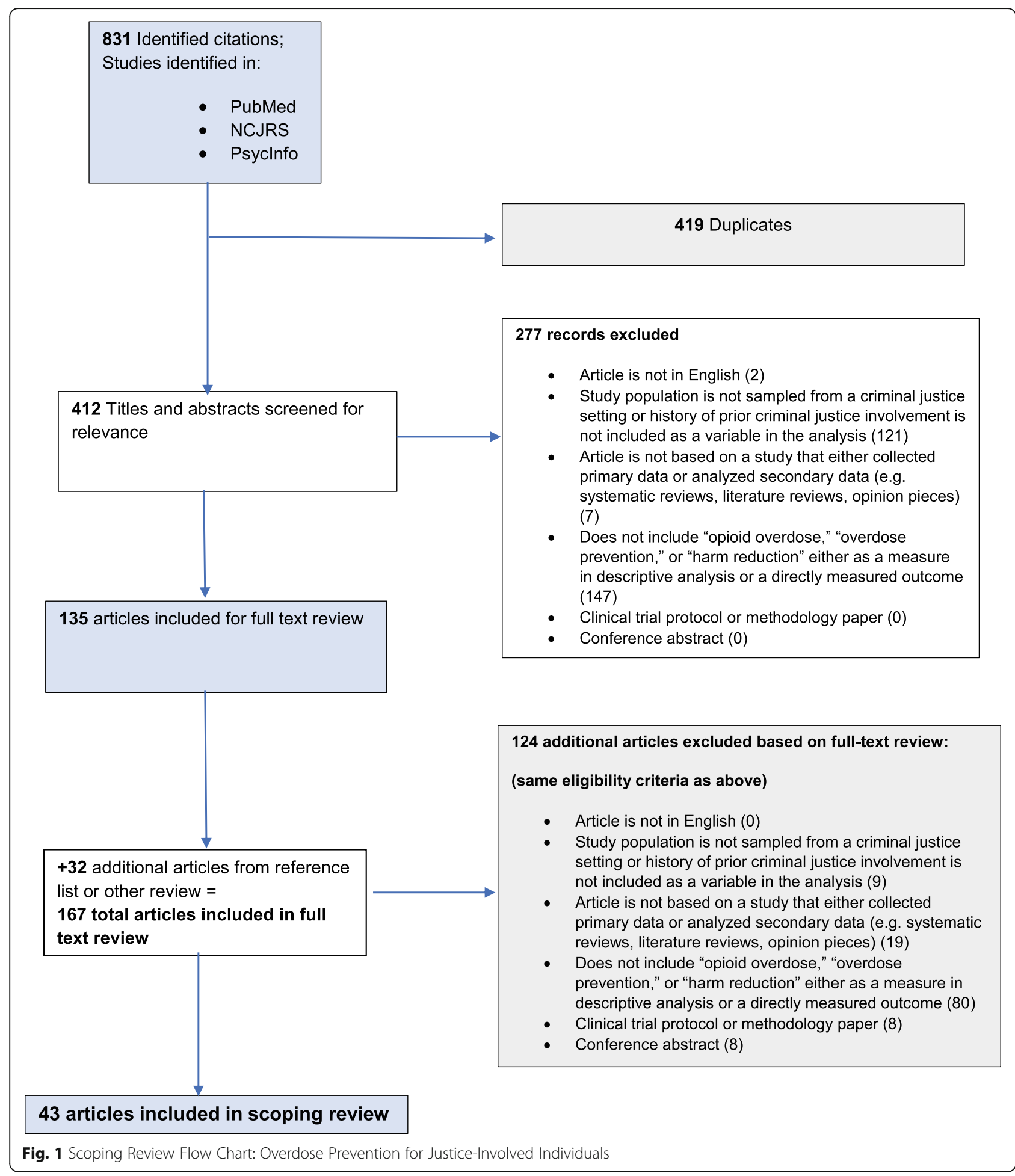

\section{Study sample}

- Twenty-eight studies sampled individuals based on their current or past involvement in, or interaction with, the criminal justice system: prison $(n=24)$, jail $(n=3)$, community corrections $(n=1)$

- Ten studies sampled individuals from community settings, including diverse community sites and street outreach $(n=6)$, syringe exchange programs 
$(n=3)$, residential substance use disorder (SUD) treatment program $(n=1)$

- Three studies used general population samples

- Two studies recruited participants from a combination of both correctional and community settings.

\section{Study design/methods}

- Nineteen quantitative studies using primary data: cross-sectional survey/structured interviews $(n=7)$, semi-structured interviews $(n=3)$, one-group pre/ post intervention surveys $(n=4)$, time series pre/ post intervention $(n=3)$, randomized controlled trial $(n=1)$, longitudinal cohort study with structured interviews $(n=1)$

- Eighteen secondary analyses of quantitative data: surveys $(n=2)$ and cohort studies with data linkage $(n=16)$;

- Six qualitative studies: qualitative interviews and/or focus groups $(n=3)$, program description/ observations $(n=2)$, and case study $(n=1)$

\section{Classification of studies into core domains and thematic analysis}

Table 1 shows the characteristics of the included studies and coding of studies into core domains for thematic analysis. Core domains were identified that addressed overdose prevention at the individual or situational level (i.e., acceptability, overdose risk), systemic level (accessibility), and programmatic level (effectiveness, feasibility). Below are operational definitions of the 5 core domains:

Acceptability: knowledge and attitudes about overdose prevention; ability to administer naloxone; interest or willingness to be trained in naloxone administration Accessibility: has naloxone available; sources where naloxone was obtained

Effectiveness: outcomes of opioid overdose prevention training and naloxone take-home programs; reductions in opioid-related overdoses following policy change or intervention

Feasibility: development and implementation of overdose prevention programs; barriers and facilitators of implementation

Participant overdose risk: temporal patterns in opioid overdose following release from prison or jail; participant characteristics associated with opioid overdose; interactions with service providers prior to overdose

\section{Acceptability}

Eight studies in this domain examined the relationship of criminal justice involvement with individuals' ability or willingness to respond to an overdose, knowledge of overdose prevention techniques, attitudes about naloxone, or willingness to learn how to administer naloxone.

A common finding was the strong association of having a personal history of overdose or having witnessed an overdose with being willing to use or learn how to use naloxone. This was evident in a survey of approximately 3700 incarcerated individuals in Los Angeles County jail [17]; approximately two-fifths (39\%) reported interest in being trained in overdose prevention and response. The largest predictor of interest was witnessing an overdose in the past year $(\mathrm{OR}=2.33$, after adjusting for other factors). Similarly, among a sample of individuals under community corrections supervision in Alabama in 2012 (67\% male), individuals who had a history of overdose were 2-3 times more likely to have witnessed an overdose or have known someone who had died from an opioid overdose; a higher percentage of these were willing to be trained on naloxone use compared with individuals who had not overdosed (59\%) or who did not use opioid (72\% vs. 32\%, respectively) [15]. Moreover, those with prior overdose history were more likely to have taken some action in response to observing an overdose, such as calling 911 or transporting the individual to a hospital, however, only $4 \%$ had administered naloxone.

In a sample of adults with a history of OUD who had been court-referred to residential SUD treatment in Michigan, over two thirds of the sample had overdosed or witnessed an overdose, however, only $56 \%$ correctly identified naloxone as an overdose prevention strategy [18]. Level of prior justice involvement did not differentiate those with knowledge of naloxone, although males who had a history of overdose were more likely to identify naloxone as a prevention strategy.

Attitudes about naloxone use were assessed among incarcerated men with a recent history of injection drug use in a cohort study in Australia [16]. Although 89\% had a history of heroin use, methamphetamine was the most prevalent substance used in the month prior to incarceration (84\%). Approximately 80-90\% stated they were willing to be trained in naloxone administration and to be revived by someone who had been trained. Factors associated with willingness to be trained included injecting drugs for more than 10 years, witnessing an opioid overdose in the past 5 years, receiving SUD treatment while incarcerated, and injecting drugs during the current incarceration. However, heroin use in the month prior to incarceration was not associated with willingness to be trained. The authors suggest overdose prevention programs should not exclusively target heroin/opioid users but should more broadly engage individuals in naloxone training prior to their release. 
Table 1 Summary of Articles Included in Scoping Review of Opioid Overdose Prevention for Justice-Involved Populations

\begin{tabular}{lccccc}
\hline Study & Study Objectives & Study Design & Sample/Setting & Key Findings & Study Implications \\
\hline Acceptability: Knowledge of overdose prevention interventions; interest and willingness to be trained in naloxone administration; ability
\end{tabular}

\section{to administer naloxone}

Bennett \&

Holloway, 2012

[14]
Cropsey, Martin, Clark,

McCullumsmith,

Lane, Hardy,

Hendricks, \&

Redmond, 2013

[15]
To determine the impact of naloxone training on knowledge of opiate overdose and confidence and willingness to take appropriate action and to examine the use of naloxone and other harm reduction actions at the time of overdose events

\section{Pre/post training}

intervention survey
521 opiate users and 4 non-opiate users sampled from 5 community sites (362) and 3 prisons (163); comparison sample of agency staff in Wales; $83 \%$ male, with a mean age of $32.9 ; 69 \%$ were currently in treatment
- Among the study participants, $68 \%$ had used heroin in the last 28 days, $44 \%$ had previously overdosed, $75 \%$ had witnessed an overdose in their lifetime, 30\% had witnessed a fatal overdose

- Knowledge about how to recognise and respond to overdose events increased among trainees across all measures.

- Confidence to administer naloxone increased from 67 to $92 \%$ and the proportion of clients who were confident to take appropriate actions at the scene of an overdose increased from a $77 \%$ pretraining to $93 \%$ posttraining; the proportion of clients who were willing to take appropriate actions increased from 91 to $97 \%$.

- Over the course of the study, there were 28 recorded uses of naloxone, resulting in 27 recoveries and one fatality characteristics, history of overdose, and response to overdose among a community corrections sample
478 adults under

\section{Survey} community corrections supervision in Alabama; $67 \%$ male
- 40\% had lifetime history of opioid use; $40 \%$ of these had a history of opioid overdose

- OD history was associated with being female, white, higher education, and willing to receive training on Naloxone use; they were also 2-3 times more likely to have witnessed an overdose or known someone who died from opioid overdose

- In response to an overdose, those who had a history of overdose were more likely than others to provide some intervention, most often calling 911 (59\%) and transporting the
- Training in OD management and the use of naloxone can bring about significant improvements in knowledge and willingness to take action.

- THN trainees also demonstrated that they were able to use naloxone successfully in OD events

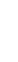


Table 1 Summary of Articles Included in Scoping Review of Opioid Overdose Prevention for Justice-Involved Populations (Continued)

\begin{tabular}{|c|c|c|c|c|c|}
\hline Study & Study Objectives & Study Design & Sample/Setting & Key Findings & Study Implications \\
\hline & & & & $\begin{array}{l}\text { individual to hospital } \\
\text { ED (33\%), although } \\
23 \% \text { provided no } \\
\text { intervention and only } \\
4 \% \text { administered } \\
\text { Naloxone }\end{array}$ & \\
\hline $\begin{array}{l}\text { Curtis, Dietze, } \\
\text { Aitken, Kirwan, } \\
\text { Kinner, Butler, \& } \\
\text { Stoové, } 2018 \\
\text { [16] }\end{array}$ & $\begin{array}{l}\text { To evaluate the } \\
\text { acceptability of THN in } \\
\text { a cohort of male } \\
\text { prisoners }\end{array}$ & $\begin{array}{l}\text { Baseline interviews with } \\
\text { participants in a } \\
\text { longitudinal cohort } \\
\text { study }\end{array}$ & $\begin{array}{l}380 \text { men from the } \\
\text { Prison and Transition } \\
\text { Health (PATH) Cohort } \\
\text { Study, all of whom } \\
\text { reported regular IDU in } \\
\text { the } 6 \text { months prior to } \\
\text { incarceration; Victoria, } \\
\text { Australia }\end{array}$ & $\begin{array}{l}\text { - } 81 \% \text { of participants } \\
\text { reported willingness } \\
\text { to undertake THN } \\
\text { training prior to } \\
\text { release. } \\
\text { - Most were willing to } \\
\text { resuscitate a friend } \\
\text { using THN if they } \\
\text { were trained (94\%) } \\
\text { and to be revived by a } \\
\text { trained peer (91\%) } \\
\text { using THN. } \\
\text { - More than } 10 \text { years } \\
\text { since first injection, } \\
\text { having witnessed an } \\
\text { opioid overdose in the } \\
\text { last } 5 \text { years, having } \\
\text { ever received alcohol } \\
\text { or other drug } \\
\text { treatment in prison, } \\
\text { and injecting drugs } \\
\text { during the current } \\
\text { prison sentence were } \\
\text { significantly associated } \\
\text { with increased odds of } \\
\text { willingness to } \\
\text { participate in a prison } \\
\text { THN program. } \\
\text { - Not specifying } \\
\text { whether they had } \\
\text { injected during their } \\
\text { prison sentence was } \\
\text { associated with } \\
\text { decreased odds of } \\
\text { willingness to } \\
\text { participate in a prison } \\
\text { THN training. }\end{array}$ & $\begin{array}{l}\text { - Identification of } \\
\text { correlates of } \\
\text { willingness to } \\
\text { participate in training, } \\
\text { such as longer } \\
\text { histories of IDU and } \\
\text { exposure to SUD } \\
\text { treatment in prison, } \\
\text { provide useful } \\
\text { information for } \\
\text { targeting the } \\
\text { promotion and } \\
\text { delivery of prison- } \\
\text { based THN } \\
\text { programmes }\end{array}$ \\
\hline $\begin{array}{l}\text { Davidson, } \\
\text { Wagner, Tokar, } \\
\text { \& Scholar, } 2019 \\
\text { [17] }\end{array}$ & $\begin{array}{l}\text { To identify individuals } \\
\text { incarcerated in jail who } \\
\text { are most likely to } \\
\text { benefit from overdose } \\
\text { prevention and } \\
\text { response (OPR) } \\
\text { programs. }\end{array}$ & Survey & $\begin{array}{l}3781 \text { jail inmates (3315 } \\
\text { men, } 466 \text { women) in } \\
\text { Los Angeles, CA; } 17 \% \text { of } \\
\text { survey sample reported } \\
\text { using opioids within } \\
\text { the last } 12 \text { months }\end{array}$ & $\begin{array}{l}\text { - } 7 \% \text { reported } \\
\text { witnessing an } \\
\text { overdose within the } \\
\text { last } 12 \text { months } \\
\text { - } 5 \% \text { report ever having } \\
\text { received MAT } \\
\text { - } 39 \% \text { reported interest } \\
\text { in being trained in } \\
\text { overdose prevention } \\
\text { and response. } \\
\text { - The single largest } \\
\text { predictor of interest in } \\
\text { OPR was being } \\
\text { present at an } \\
\text { overdose in the past } \\
\text { year. }\end{array}$ & $\begin{array}{l}\text { - Overdose Prevention } \\
\text { and Response training } \\
\text { should be provided to } \\
\text { all inmates who opt-in } \\
\text { to receive training } \\
\text { regardless of other risk } \\
\text { factors. } \\
\text { - Incarceration could } \\
\text { represent a significant } \\
\text { opportunity to provide } \\
\text { evidence-based } \\
\text { treatments, including } \\
\text { MAT. }\end{array}$ \\
\hline $\begin{array}{l}\text { Gicquelais, } \\
\text { Mezuk, Foxman, } \\
\text { Thomas, \& } \\
\text { Bohnert, } 2019 \\
\text { [18] }\end{array}$ & $\begin{array}{l}\text { To obtain information } \\
\text { from justice-involved } \\
\text { individuals in a drug } \\
\text { treatment program that } \\
\text { can be used to inform } \\
\text { OEND planning }\end{array}$ & Survey & $\begin{array}{l}514 \text { adults sampled } \\
\text { from residential SUD } \\
\text { treatment program, } \\
\text { whose treatment was } \\
\text { prompted by the CJS } \\
\text { and had a history of }\end{array}$ & $\begin{array}{l}\text {-56\% of participants } \\
\text { correctly identified } \\
\text { naloxone as an opioid } \\
\text { overdose treatment, } \\
\text { although } 68 \% \text { had } \\
\text { experienced an }\end{array}$ & $\begin{array}{l}\text { - All individuals with } \\
\text { OUD in criminal justice } \\
\text { diversion programs } \\
\text { could benefit from } \\
\text { OEND given the high } \\
\text { propensity to }\end{array}$ \\
\hline
\end{tabular}


Table 1 Summary of Articles Included in Scoping Review of Opioid Overdose Prevention for Justice-Involved Populations (Continued)

\begin{tabular}{|c|c|c|c|c|c|}
\hline Study & Study Objectives & Study Design & Sample/Setting & Key Findings & Study Implications \\
\hline & & & $\begin{array}{l}\text { heroin use or opioid } \\
\text { misuse in Michigan }\end{array}$ & $\begin{array}{l}\text { overdose and 79\% } \\
\text { had witnessed another } \\
\text { person overdose. } \\
\text { - Two latent justice } \\
\text { involvement classes } \\
\text { were identified (low } \\
\text { and high), however, } \\
\text { justice involvement } \\
\text { was not associated } \\
\text { with naloxone } \\
\text { knowledge. } \\
\text { - Male participants who } \\
\text { had personally } \\
\text { overdosed more often } \\
\text { identified naloxone as } \\
\text { an overdose treatment } \\
\text { after adjustment for } \\
\text { covariates }\end{array}$ & $\begin{array}{l}\text { experience and } \\
\text { witness overdoses and } \\
\text { low naloxone } \\
\text { knowledge across } \\
\text { justice involvement } \\
\text { backgrounds among } \\
\text { both men and women }\end{array}$ \\
\hline $\begin{array}{l}\text { Holloway, Hills, } \\
\text { \& May, } 2018 \text { [19] }\end{array}$ & $\begin{array}{l}\text { To apply the concept of } \\
\text { the 'risk environment' } \\
\text { to examine how } \\
\text { witnesses respond to } \\
\text { opiate overdose; and to } \\
\text { examine the micro- and } \\
\text { macro-level factors the } \\
\text { impede the } \\
\text { implementation of } \\
\text { harm reduction } \\
\text { techniques in response } \\
\text { to an overdose }\end{array}$ & $\begin{array}{l}\text { Semi-structured } \\
\text { interviews }\end{array}$ & $\begin{array}{l}55 \text { participants recruited } \\
\text { from statutory and third } \\
\text { sector drug treatment } \\
\text { providers in } 5 \text { towns/ } \\
\text { cities in South Wales } \\
\text { and in two Welsh } \\
\text { prisons; all had ever } \\
\text { used heroin and 95\% } \\
\text { had ever injected; 78\% } \\
\text { had ever been in prison } \\
\text { and } 47 \% \text { were currently } \\
\text { in prison }\end{array}$ & 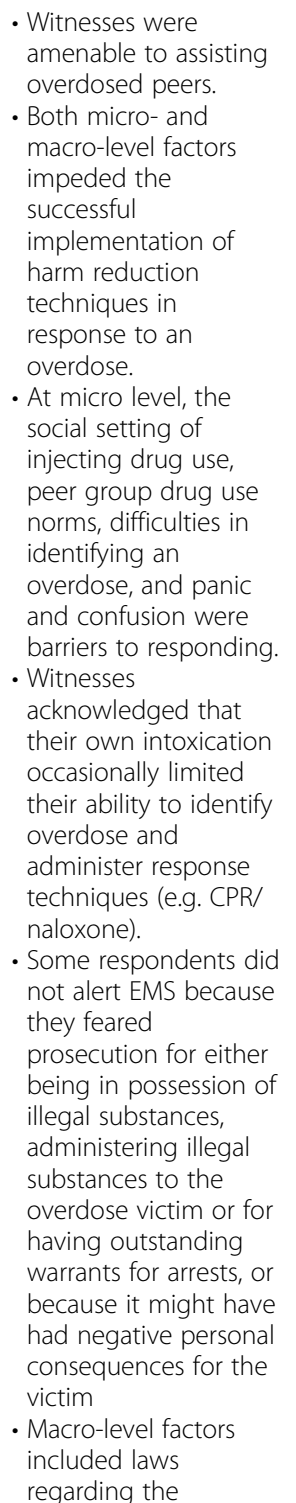 & $\begin{array}{l}\text { - Context specific micro- } \\
\text { and macro- } \\
\text { environmental factors } \\
\text { mitigate effective and } \\
\text { immediate overdose } \\
\text { intervention } \\
\text { - Prevention policies } \\
\text { need to address the } \\
\text { contextual factors that } \\
\text { restrict IDU's attempts } \\
\text { to enact effective } \\
\text { overdose response } \\
\text { techniques through } \\
\text { innovative measures } \\
\text { that enable } \\
\text { intervention. }\end{array}$ \\
\hline
\end{tabular}


Table 1 Summary of Articles Included in Scoping Review of Opioid Overdose Prevention for Justice-Involved Populations (Continued)

\begin{tabular}{|c|c|c|c|c|c|}
\hline Study & Study Objectives & Study Design & Sample/Setting & Key Findings & Study Implications \\
\hline & & & & $\begin{array}{l}\text { possession of drugs } \\
\text { and harm reduction } \\
\text { discourse that also } \\
\text { limited the uptake of } \\
\text { overdose response } \\
\text { techniques }\end{array}$ & \\
\hline $\begin{array}{l}\text { Koester, Mueller, } \\
\text { Raville, } \\
\text { Langegger, \& } \\
\text { Binswanger, } \\
2017 \text { [20] }\end{array}$ & $\begin{array}{l}\text { To apply the concept of } \\
\text { the "risk environment" } \\
\text { (i.e., social, political, } \\
\text { economic) to } \\
\text { understanding } \\
\text { responses to opioid } \\
\text { overdose within the } \\
\text { context of a recent } \\
\text { Good Samaritan law by } \\
\text { describing PWIDs' } \\
\text { experiences of reversing } \\
\text { overdoses and their } \\
\text { decision whether to call } \\
\text { for EMS support. }\end{array}$ & $\begin{array}{l}\text { Semi-structured } \\
\text { interviews and } \\
\text { fieldwork observations }\end{array}$ & $\begin{array}{l}\text { Data combined from } 2 \\
\text { studies: } \\
\text { 1) semi-structured } \\
\text { interviews with } 13 \\
\text { persons who inject } \\
\text { drugs ( } 5 \text { women, } 8 \\
\text { men); } \\
\text { 2) fieldwork } \\
\text { observations and } \\
\text { qualitative interviews } \\
\text { with } 24 \text { individuals } \\
\text { sampled from a syringe } \\
\text { exchange program (19 } \\
\text { men, } 5 \text { women) in } \\
\text { Denver, CO }\end{array}$ & $\begin{array}{l}\text { - Despite being trained } \\
\text { in OEND, most } \\
\text { participants stated } \\
\text { they had not called } \\
911 \text { (EMS) after } \\
\text { reversing an overdose } \\
\text { - Most frequent reason } \\
\text { was fear that despite } \\
\text { the Good Samaritan } \\
\text { law, a police response } \\
\text { would result in arrest } \\
\text { of the victim and/or } \\
\text { witness for } \\
\text { outstanding warrants } \\
\text { or sentence violations. } \\
\text { - Fears were based on } \\
\text { individual and } \\
\text { collective experience, } \\
\text { and reinforced by the } \\
\text { city's aggressive } \\
\text { approach to } \\
\text { managing } \\
\text { homelessness through } \\
\text { increased enforcement } \\
\text { of misdemeanors and } \\
\text { ordinances, including } \\
\text { a camping ban, to } \\
\text { control space. } \\
\text { - Participants expressed } \\
\text { concerns that an EMS } \\
\text { intervention would } \\
\text { jeopardize their public } \\
\text { housing. }\end{array}$ & $\begin{array}{l}\text { - The immunity } \\
\text { provided by the Good } \\
\text { Samaritan law does } \\
\text { not address } \\
\text { individuals' fears that } \\
\text { their current legal } \\
\text { status as well as the } \\
\text { victim's will result in } \\
\text { arrest and } \\
\text { incarceration. As } \\
\text { currently conceived, } \\
\text { the Good Samaritan } \\
\text { law does not provide } \\
\text { immunity for } \\
\text { individuals who inject } \\
\text { drugs and are already } \\
\text { enmeshed in the CJS, } \\
\text { or are fearful of losing } \\
\text { their housing. }\end{array}$ \\
\hline $\begin{array}{l}\text { Petterson \& } \\
\text { Madah-Amiri, } \\
2017 \text { [21] }\end{array}$ & $\begin{array}{l}\text { To assess knowledge of } \\
\text { opioid OD among } \\
\text { inmates at risk of } \\
\text { witnessing or } \\
\text { experiencing an OD } \\
\text { before and after a brief } \\
\text { training session about } \\
\text { naloxone prior to re- } \\
\text { entry }\end{array}$ & $\begin{array}{l}\text { Pre/post training } \\
\text { intervention survey }\end{array}$ & $\begin{array}{l}31 \text { current or former } \\
\text { opioid-using offenders } \\
\text { within } 6 \text { months of } \\
\text { release from } \\
\text { incarceration in Oslo, } \\
\text { Norway; half of the } \\
\text { participants were } \\
\text { receiving methadone } \\
\text { treatment prior to } \\
\text { prison; } 100 \% \text { male }\end{array}$ & $\begin{array}{l}\text { - Nearly every } \\
\text { participant reported } \\
\text { that they previously } \\
\text { had witnessed an } \\
\text { overdose and almost } \\
\text { half had experienced } \\
\text { between } 1 \text { and } 10 \\
\text { personally. } \\
\text { - Participating inmates } \\
\text { were found to have a } \\
\text { high baseline } \\
\text { knowledge of risk } \\
\text { factors, symptoms and } \\
\text { care regarding opioid } \\
\text { overdoses on an } \\
\text { Opioid Overdose } \\
\text { Knowledge Scale } \\
\text { - A brief naloxone } \\
\text { training session on } \\
\text { how to recognize and } \\
\text { respond to an opioid } \\
\text { overdose with } \\
\text { naloxone and how to } \\
\text { assemble and use the } \\
\text { device, significantly } \\
\text { improved knowledge } \\
\text { regarding naloxone }\end{array}$ & $\begin{array}{l}\text { - Naloxone training in } \\
\text { the prison setting may } \\
\text { be an effective means } \\
\text { of improving } \\
\text { knowledge about } \\
\text { opioid overdose } \\
\text { within a vulnerable } \\
\text { group. }\end{array}$ \\
\hline
\end{tabular}


Table 1 Summary of Articles Included in Scoping Review of Opioid Overdose Prevention for Justice-Involved Populations (Continued)

\begin{tabular}{|c|c|c|c|c|}
\hline Study & Study Objectives & Study Design & Sample/Setting & Key Findings \\
\hline & & & & $\begin{array}{l}\text { use, effect, } \\
\text { administration, and } \\
\text { aftercare procedures. }\end{array}$ \\
\hline
\end{tabular}

\section{Accessibility: Access to naloxone; receipt of naloxone from different sources}

Barocas, Baker, To improve Survey

Hull, Stokes, \& understanding of the

Westergaard, acceptability and

2015 [22] current uptake of naloxone-based overdose prevention training among people who inject drugs who interact with the CJS.

Bird, McAuley, To examine changes

Munro, over time in receipt of

Hutchinson, \& THN from prisons

Taylor, 2017 [23] among participants in Scotland's ongoing Needle Exchange Surveillance Initiative (NESI) program

McAuley, Munro, To address three

Bird, specific evidence gaps:

Hutchinson, (1) the extent of

Goldberg, \& naloxone supply to

Taylor, 2016 [24] PWID; (2) supply-source (community or prisons); and (3) the carriage of naloxone among PWID.

543 individuals who inject drugs using a free multi-site syringe exchange program

August, 2012 in Wisconsin; $43 \%$ had a history of incarceration

Secondary analysis of interview data

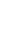

A demographically representative sample of between 2000 and 3000 PWID (80\% having injected within the past 6 months) from across Scotland in which interviews are conducted every 2 years between June -

Survey

Participants in Scotland's Needle Exchange Surveillance Initiative (NESI) in 20112012 and 2013-2014 over $90 \%$ report heroin as the drug injected most often within the past 6 months.
- Respondents who observed an overdose were more likely to have a history of incarceration;

- Respondents who were trained to administer naloxone were more likely to have a history of incarceration.

- No participants reported receiving this training in prison or jail but received training from syringe exchange program staff.

- Controlling for pastyear incarceration rate and average duration of incarceration, among individuals in the NESI sample who received take-home naloxone at release from prison:

- $67 \%$ were female vs. $39 \%$ were male - $48 \%$ were younger than 35 years vs. $37 \%$ older

- The proportion whose naloxone was most recently received from prison was about 13\% irrespective of recency of injecting

Study Implications training is made available through community-based syringe exchange programs, CJSinvolved clients will use the service and administer naloxone in practice.

The study identified heterogeneity in provision of THN by sex, age-group, homelessness, and recency of injecting, with greater provision for people who were younger than 35 years, homeless, and had injected drugs in the past 6 months

- Study examined the interface between THN and communitybased-provision of naloxone and how changes in THN may reflect greater access to community-based provision.

- The proportion of NESI - Individuals at risk of participants who overdose may reported that they had calculate their level of been prescribed risk and decision naloxone within the last year increased significantly from $8 \%$ in $2011-2012$ to $32 \%$ in 2013-2014.

- In contrast, the proportion of NESI participants who carried naloxone with them on the day they were interviewed decreased significantly from 16\% in 2011 2012 to $5 \%$ in $2013-$ 2014.

- The proportion of participants reporting that their last whether to carry naloxone based on their perceptions of availability of naloxone in the community (i.e., diffusion of responsibility).

- PWIDs may also be reluctant to carry naloxone on their person because of fear of coming into contact with the police. The naloxone kit provided by the NNP is in a bulky, clinically labelled yellow box, making it 
Table 1 Summary of Articles Included in Scoping Review of Opioid Overdose Prevention for Justice-Involved Populations (Continued)

\begin{tabular}{|c|c|c|c|c|c|}
\hline Study & Study Objectives & Study Design & Sample/Setting & Key Findings & Study Implications \\
\hline & & & & $\begin{array}{l}\text { naloxone supply was } \\
\text { made via the prison } \\
\text { system was stable } \\
\text { across the two } \\
\text { surveys: } 16 \% \text { in } 2011- \\
2012 \text { to } 19 \% \text { in } 2013- \\
2014 . \\
\text { - Controlling for } \\
\text { duration of prison } \\
\text { sentence, both } \\
\text { community services } \\
\text { and prisons were } \\
\text { equally efficient at } \\
\text { targeting their } \\
\text { naloxone supplies to } \\
\text { PWID. } \\
\text { - Carriage was lowest } \\
\text { among those who } \\
\text { had not injected in } \\
\text { the previous 6-months } \\
\text { therefore it is possible } \\
\text { that self-reported } \\
\text { naloxone carriage is } \\
\text { associated with } \\
\text { current injecting } \\
\text { behavior and } \\
\text { perceived risk of } \\
\text { experiencing an } \\
\text { overdose. }\end{array}$ & $\begin{array}{l}\text { less discreet and less } \\
\text { portable. It is plausible } \\
\text { that the physical } \\
\text { properties of naloxone } \\
\text { kits may influence } \\
\text { carriage rates among } \\
\text { PWIDs }\end{array}$ \\
\hline $\begin{array}{l}\text { O'Hallaran, } \\
\text { Cullen, Njoroge, } \\
\text { Jessop, Smith, } \\
\text { Hope, \& Ncube, } \\
2017 \text { [25] }\end{array}$ & $\begin{array}{l}\text { To monitor the impact } \\
\text { of the } 2015 \text { policy } \\
\text { change to improve } \\
\text { naloxone availability in } \\
\text { the U.K. using national- } \\
\text { level data on the extent } \\
\text { of self-reported } \\
\text { overdose and self- } \\
\text { reported receipt of } \\
\text { naloxone among PWID } \\
\text { in the United Kingdom }\end{array}$ & $\begin{array}{l}\text { Secondary analyses of } \\
\text { cross-sectional surveys }\end{array}$ & $\begin{array}{l}3850 \text { PWID at sentinel } \\
\text { sites located } \\
\text { throughout the UK that } \\
\text { voluntarily participated } \\
\text { in annual surveys in } \\
2013 \text { and } 2014\end{array}$ & $\begin{array}{l}\text {-91\% of the sample } \\
\text { injected heroin; 15\% } \\
\text { reported overdosing } \\
\text { during the preceding } \\
\text { year } \\
\text { - There were no } \\
\text { differences in the } \\
\text { proportion reporting } \\
\text { OD by age or gender, } \\
\text { but OD was more } \\
\text { common among } \\
\text { those who: injected } \\
\text { multiple drugs; } \\
\text { recently ceased } \\
\text { addiction treatment; } \\
\text { injected with used } \\
\text { needles/ syringes; ever } \\
\text { had transactional sex; } \\
\text { had used a sexual } \\
\text { health clinic or } \\
\text { emergency } \\
\text { department, and lived } \\
\text { in Wales or No. } \\
\text { Ireland. } \\
\text { - Of those reporting an } \\
\text { OD during the past } \\
\text { year, two fifths } \\
\text { reported } 2 \text { or more } \\
\text { ODs and one half } \\
\text { reported receiving } \\
\text { naloxone. } \\
\text { - Those reporting } \\
\text { naloxone receipt in } \\
\text { the preceding year } \\
\text { were more likely to: } \\
\text { live in Wales or } \\
\text { Northern Ireland; ever }\end{array}$ & $\begin{array}{l}\text { - Interventions to } \\
\text { prevent OD should } \\
\text { promote naloxone } \\
\text { awareness and access, } \\
\text { and target those who: } \\
\text { are poly-drug injectors, } \\
\text { have ceased } \\
\text { treatment, share } \\
\text { needles/ syringes and } \\
\text { whose drug use links } \\
\text { to sexual activity. } \\
\text { - History of } \\
\text { incarceration was } \\
\text { associated with having } \\
\text { received naloxone at } \\
\text { last OD, controlling for } \\
\text { other individual } \\
\text { characteristics }\end{array}$ \\
\hline
\end{tabular}


Table 1 Summary of Articles Included in Scoping Review of Opioid Overdose Prevention for Justice-Involved Populations (Continued)

\begin{tabular}{|c|c|c|c|c|c|}
\hline Study & Study Objectives & Study Design & Sample/Setting & Key Findings & Study Implications \\
\hline & & & & $\begin{array}{l}\text { received used } \\
\text { needles/syringes; ever } \\
\text { been imprisoned (AOR } \\
=1.59 \text { ); and less likely } \\
\text { to have injected two } \\
\text { drug types. }\end{array}$ & \\
\hline
\end{tabular}

\section{Effectiveness: Outcomes of opioid overdose prevention training and naloxone take-home programs; reductions in opioid-related} overdoses

Bird \& McAuley, To assess drug-related 2019 [26] deaths before and after implementation of Scotland's National Naloxone Program and scale-up of naloxone distribution over time.
Bird, McAuley, To assess the

Perry, \& Hunter, effectiveness of 2016 [27] post implementa-tion program model among individuals released from prisons and hospitals from 2006 to 2016 in Scotland
Time series analysis pre/ Opioid-related deaths of NNP; evaluation of

- The primary outcome for Scotland's NNP was a reduction from 10 to $7 \%$ in ORDs within 4 weeks of prison release, which is a reduction of $50 \%$; secondarily, there was a reduction of $4 \%$ from 10 to $9 \%$ within 4 weeks of hospital release.

- In 6 years (2011-16), Scotland's NNP supplied almost 36,000 naloxone kits to people at risk of opioid-related overdose.

- The distribution target of 8000 naloxone kits (20 times Scotland's mean number of ORDs per annum in 2006-10) was met in 2014-16 when the primary outcome was halved.

- ORDs have increased since the NNP was introduced, with 709 ORDs in 2017, of whom 545 individuals (77\%) were 35 years or older.

Scotland's National Naloxone Programme (NNP) by comparison between two time periods, 2006-10 and 2011-13, corresponding to before and after NNP started in January 2011; and to assess costeffectiveness of the program.
Time series analysis pre/ Individuals released post implementation of from prison in Scotland NNP in:

1) 2006-10: $n=1970$; Opioid-related deaths (ORD) $n=193$;

2) 2011-2013:

$n=1212 ;$ ORDs $n=76$
- In 2006-10, 9.8\% of ORDs (193 of 1970) were in people released from prison within 4 weeks of death, whereas only $6.3 \%$ of ORDs in 2011 13 followed prison release (76 of 1212, $P$ $<0.001$ ), which is a difference of 3.5\%

(95\% Cl = 1.6-5.4\%).

- This reduction in the proportion of prison release ORDs

translates into 42 fewer prison release ORDs $(95 \% \mathrm{Cl}=19$ 65) during 2011-13, when 12,000 naloxone kits were issued at current prescription
- The national program model has been adapted and implemented in England; Wales; Norway; British Columbia, Canada; progress has been slower in Australia and the U.S.
- This is the first study to evaluate a national naloxone programme at a population level with before/after analyses by design at 3 years and 5 years. - The study found that there was a $20-36 \%$ reduction in the proportion of ORDs that occurred in the 4 weeks following release from prison (from 9.8 to 6.3\%) following establishment of Scotland's NNP. 
Table 1 Summary of Articles Included in Scoping Review of Opioid Overdose Prevention for Justice-Involved Populations (Continued)

\begin{tabular}{|c|c|c|c|c|c|}
\hline Study & Study Objectives & Study Design & Sample/Setting & Key Findings & Study Implications \\
\hline & & & & cost of $£ 225,000$. & \\
\hline $\begin{array}{l}\text { Green, Ray, } \\
\text { Bowman, } \\
\text { McKenzie, \& } \\
\text { Rich, } 2014 \text { [28] }\end{array}$ & $\begin{array}{l}\text { To describe two case } \\
\text { studies of successful } \\
\text { self-administration of } \\
\text { intranasal naloxone } \\
\text { during an opioid } \\
\text { overdose. }\end{array}$ & Case study & $\begin{array}{l}\text { Two people (one male } \\
\text { and one female) with } \\
\text { opiate use histories } \\
\text { who self-administered } \\
\text { intranasal naloxone } \\
\text { following their release } \\
\text { from prison in Rhode } \\
\text { Island }\end{array}$ & $\begin{array}{l}\text { - Describes two cases of } \\
\text { individuals who had } \\
\text { been trained in the } \\
\text { high risk of overdose } \\
\text { after release from } \\
\text { incarceration and on } \\
\text { how to use naloxone, } \\
\text { which was } \\
\text { instrumental in their } \\
\text { successful self- } \\
\text { administration of } \\
\text { naloxone to reverse } \\
\text { opioid overdose } \\
\text { following their release } \\
\text { from prison. }\end{array}$ & $\begin{array}{l}\text { - Training of people at } \\
\text { risk of overdose, } \\
\text { including inmates } \\
\text { about to be released } \\
\text { and people who } \\
\text { actively use drugs, as } \\
\text { well as the members } \\
\text { of their social and } \\
\text { drug use networks, on } \\
\text { the signs of overdose } \\
\text { and how to respond } \\
\text { with naloxone is } \\
\text { possible, effective, and } \\
\text { cost-effective. }\end{array}$ \\
\hline $\begin{array}{l}\text { Huxley-Reicher, } \\
\text { Maldjian, } \\
\text { Winkelstein, } \\
\text { Siegler, Panone, } \\
\text { Tuazon, Nolan, } \\
\text { Jordan, } \\
\text { MacDonald, \& } \\
\text { Kunins, } 2017 \\
\text { [29] }\end{array}$ & $\begin{array}{l}\text { To determine rates of } \\
\text { overdose witnessing } \\
\text { and naloxone use } \\
\text { among overdose } \\
\text { rescue-trained visitors } \\
\text { to the New York City } \\
\text { jails. }\end{array}$ & $\begin{array}{l}\text { Pre/post intervention } \\
\text { survey }\end{array}$ & $\begin{array}{l}283 \text { individuals visiting } \\
\text { incarcerated persons, } \\
\text { Rikers Island, New York }\end{array}$ & $\begin{array}{l}\text { - } 382 \text { visitors were } \\
\text { trained over } 5 \text { days in } \\
\text { overdose rescue at the } \\
\text { Rikers Island Visitors } \\
\text { Center; of these, } 283 \\
\text { returned to request a } \\
\text { naloxone kit and were } \\
\text { enrolled in the study; } \\
226 \text { completed the 6- } \\
\text { month follow up. } \\
\text { - } 40 \text { participants (14\% of } \\
\text { the total enrolled } n= \\
283 \text { ) had witnessed at } \\
\text { least one overdose } \\
\text { during the study } \\
\text { period; there was a } \\
\text { total of } 70 \text { overdose } \\
\text { events witnessed and } \\
87 \% \text { were known to } \\
\text { have survived. } \\
\text { - Overall, } 28 \text { (10\%) study } \\
\text { participants reported } \\
\text { administering } \\
\text { naloxone at least once } \\
\text { during the study } \\
\text { period; in } 17 \% \text { of } \\
\text { cases the recipient } \\
\text { had been recently } \\
\text { released from jail or } \\
\text { prison }\end{array}$ & $\begin{array}{l}\text { - Training visitors to } \\
\text { incarcerated } \\
\text { individuals in overdose } \\
\text { rescue is an effective } \\
\text { strategy to reach a } \\
\text { population of } \\
\text { potential overdose } \\
\text { responders. }\end{array}$ \\
\hline $\begin{array}{l}\text { Kobayashi, } \\
\text { Green, Bowman, } \\
\text { Ray, McKenzie, \& } \\
\text { Rich, } 2017 \text { [30] }\end{array}$ & $\begin{array}{l}\text { To evaluate an } \\
\text { experimental program } \\
\text { that educated, trained } \\
\text { and assessed at-risk, } \\
\text { prisoners on opioid } \\
\text { overdose prevention, } \\
\text { recognition and } \\
\text { layperson management } \\
\text { with intranasal } \\
\text { naloxone using } \\
\text { simulation techniques. }\end{array}$ & $\begin{array}{l}\text { Pre/post training } \\
\text { intervention survey }\end{array}$ & $\begin{array}{l}\text { Inmates who were } \\
\text { within } 4 \text { weeks of } \\
\text { release from the Rhode } \\
\text { Island Department of } \\
\text { Corrections in Cranston, } \\
\text { Rl; } n=85 \text { completed } \\
\text { baseline assessment, } \\
\text { intervention, and } \\
\text { follow-up assessment }\end{array}$ & $\begin{array}{l}\text { - } 38(35.5 \%) \text { and } 75 \\
\text { (70.1\%) subjects had } \\
\text { personally experienced } \\
\text { or witnessed an } \\
\text { opioid OD, } \\
\text { respectively; none had } \\
\text { previously been } \\
\text { trained to respond to } \\
\text { ODs or obtained a } \\
\text { naloxone rescue kit } \\
\text { - } 44 \text { participants (51.8\%) } \\
\text { correctly administered } \\
\text { naloxone; } 16 \\
\text { additional subjects } \\
\text { (18.8\%) sub- optimally } \\
\text { administered } \\
\text { naloxone. } \\
\text { - Non-indicated actions, } \\
\text { e.g., chest }\end{array}$ & $\begin{array}{l}\text { - More than half of the } \\
\text { study participants } \\
\text { correctly delivered } \\
\text { resuscitative doses of } \\
\text { IN naloxone with } \\
\text { timeliness comparable } \\
\text { to paramedic students. } \\
\text { - Simulation can be } \\
\text { applied to outreach } \\
\text { efforts directed } \\
\text { towards inmate target } \\
\text { populations housed in } \\
\text { intrinsically limiting } \\
\text { environments and } \\
\text { enable them to learn } \\
\text { and practice the } \\
\text { intervention for } \\
\text { responding to opioid } \\
\text { overdose, which is a }\end{array}$ \\
\hline
\end{tabular}


Table 1 Summary of Articles Included in Scoping Review of Opioid Overdose Prevention for Justice-Involved Populations (Continued)

\begin{tabular}{|c|c|c|c|c|c|}
\hline Study & Study Objectives & Study Design & Sample/Setting & Key Findings & Study Implications \\
\hline & & & & $\begin{array}{l}\text { compressions, were } \\
\text { observed in } 49.4 \% \text { of } \\
\text { simulations. } \\
\text { - Simulated resuscitative } \\
\text { actions by } 80 \text { subjects } \\
(94.1 \%) \text { were } \\
\text { determined post-hoc } \\
\text { to be beneficial overall } \\
\text { for patients } \\
\text { overdosing on opioids }\end{array}$ & $\begin{array}{l}\text { high probability event } \\
\text { following release }\end{array}$ \\
\hline $\begin{array}{l}\text { Parmar, Strang, } \\
\text { Choo, Meade, \& } \\
\text { Bird, } 2016[31]\end{array}$ & $\begin{array}{l}\text { To examine the } \\
\text { feasibility of a large- } \\
\text { scale naloxone } \\
\text { distribution program for } \\
\text { prisoners preparing for } \\
\text { re-entry and to } \\
\text { determine its impact on } \\
\text { overdose rates }\end{array}$ & $\mathrm{RCT}$ & $\begin{array}{l}1685 \text { heroin injecting } \\
\text { offenders scheduled to } \\
\text { be released from prison } \\
\text { within } 3 \text { months and } \\
\text { who had been in prison } \\
\text { at least } 7 \text { days at study } \\
\text { baseline; from } 16 \\
\text { prisons in England; } 98 \% \\
\text { male }\end{array}$ & $\begin{array}{l}\text { - There was a high rate } \\
\text { of consent among } \\
\text { prisons and offenders } \\
\text { to participate in the } \\
\text { program; however, the } \\
\text { study stopped early } \\
\text { due to the finding } \\
\text { that only one-third of } \\
\text { naloxone } \\
\text { administrations were } \\
\text { to the former } \\
\text { offender. } \\
\text { - There were } 9 \\
\text { overdose deaths } \\
\text { among offenders } \\
\text { within } 12 \text { weeks of } \\
\text { reentry. }\end{array}$ & $\begin{array}{l}\text { - Naloxone access may } \\
\text { introduce some risk } \\
\text { compensation, but } \\
\text { there is insufficient } \\
\text { evidence to draw a } \\
\text { conclusion. }\end{array}$ \\
\hline $\begin{array}{l}\text { Wenger, } \\
\text { Showalter, } \\
\text { Lambdin, Leiva, } \\
\text { Wheeler, } \\
\text { Davidson, Coffin, } \\
\text { Binswanger, \& } \\
\text { Kral, } 2019 \text { [32] }\end{array}$ & $\begin{array}{l}\text { To evaluate a take- } \\
\text { home naloxone } \\
\text { program for individuals } \\
\text { being released from jail }\end{array}$ & $\begin{array}{l}\text { Surveys and program } \\
\text { documenta-tion }\end{array}$ & $\begin{array}{l}637 \text { participants who } \\
\text { received naloxone kit } \\
\text { upon release from jail in } \\
\text { San Francisco, CA }\end{array}$ & $\begin{array}{l}\text { - During } 4 \text { years of } \\
\text { operation, } 637 \text { people } \\
\text { participated; } 67 \% \\
\text { received naloxone } \\
\text { upon release, of } \\
\text { whom only } 3.5 \% \text { had } \\
\text { been previously } \\
\text { trained in community- } \\
\text { based OEND } \\
\text { programs. } \\
\text { - Of those who received } \\
\text { naloxone, 32\% } \\
\text { reported reversing an } \\
\text { overdose and } 44 \% \\
\text { received refills after } \\
\text { reentry } \\
\text { - } 190 \text { (96\%) of these } \\
\text { individuals received } \\
\text { their refill at a syringe } \\
\text { access program or } \\
\text { other community- } \\
\text { based program and } 8 \\
\text { (4\%) received their } \\
\text { refill at the jail during } \\
\text { a subsequent } \\
\text { incarceration. } \\
\text { - The most frequent } \\
\text { reasons for getting a } \\
\text { naloxone refill were } \\
\text { that it was lost (33\%), } \\
\text { had been used to } \\
\text { reverse an overdose } \\
\text { (32\%), had been stolen } \\
\text { (13\%), and had been } \\
\text { given away to } \\
\text { someone who needed } \\
\text { it (12\%). }\end{array}$ & $\begin{array}{l}\text { - The study provides } \\
\text { evidence that } \\
\text { implementation of } \\
\text { OEND in CJS is } \\
\text { feasible and reaches } \\
\text { people who have not } \\
\text { previously been } \\
\text { trained as well as } \\
\text { those willing to act as } \\
\text { overdose responders. } \\
\text { - Demonstrates } \\
\text { successful } \\
\text { collaboration among } \\
\text { the jail, several county } \\
\text { agencies, and } \\
\text { community partners } \\
\text { - Participation in OEND } \\
\text { programs helps } \\
\text { individuals minimize } \\
\text { drug-related harm and } \\
\text { encourages them to } \\
\text { take on new prosocial } \\
\text { roles in their } \\
\text { community as peer } \\
\text { educators and } \\
\text { "overdose responders," } \\
\text { as participants often } \\
\text { teach others in their } \\
\text { communities about } \\
\text { overdose risk and } \\
\text { response. }\end{array}$ \\
\hline
\end{tabular}


Table 1 Summary of Articles Included in Scoping Review of Opioid Overdose Prevention for Justice-Involved Populations (Continued)

\begin{tabular}{|c|c|c|}
\hline Study & Study Objectives & Study Design \\
\hline \multicolumn{3}{|c|}{ Feasibility: Development and implementation of overdose preventi } \\
\hline $\begin{array}{l}\text { Green, Bowman, } \\
\text { Ray, McKenzie, } \\
\text { Lord, \& Rich, } \\
2015 \text { [33] }\end{array}$ & $\begin{array}{l}\text { To create and test the } \\
\text { acceptability of a new } \\
\text { DVD on overdose } \\
\text { prevention for former } \\
\text { prisoners based on } \\
\text { input and feedback } \\
\text { from formerly } \\
\text { incarcerated injection } \\
\text { drug users, national } \\
\text { experts, and overdose } \\
\text { prevention staff. }\end{array}$ & $\begin{array}{l}\text { 1) Formative evaluation: } \\
\text { Systematic review of } \\
\text { educational videos and } \\
\text { 2) Video development } \\
\text { using community-based } \\
\text { participatory process } \\
\text { that included } 3 \text { focus } \\
\text { groups, consultations } \\
\text { with national expert } \\
\text { groups and OD } \\
\text { prevention } \\
\text { program staff, and } \\
\text { ongoing presentations } \\
\text { to correctional staff and } \\
\text { leadership }\end{array}$ \\
\hline
\end{tabular}

Horsburgh \& McAuley, 2018 [34]
To describe the development of the National Naloxone Programme in Scotland within the Scottish Prison Service with a focus on its delivery model, challenges, and developments.

Sample/Setting

Key Findings

Study Implications

Former prisoners and current or former injection drug users ( $n$ $=4$ ), recruited at syringe exchange program in Providence, Rhode Island
Qualitative: Program description and observations
Prisons in Scotland

Prisons in Scotland

- Review of nine videos

3 contained theory-

based learning

components, and only

one also contained

peer-based content;

none directly

addressed post-

incarceration overdose

prevention.

- Created 19-min film

Staying Alive on the

Outside, using

Bandura's Social

Learning Theory and

incorporates

interviews,

conversation and

model training

sessions by peers, who

discuss the challenges

of re-entry from

prison, OUD and

relapse, and

misconceptions about

opioid tolerance and

OD.

- Viewers learn

strategies to avoid

overdose while using

opioids and what to

do in an overdose.

- Peer 'learners' and

peer 'trainers' model

the dissemination of

education and

naloxone

administration.

- Group training sessions were problematic:

- From an operational perspective, organising key personnel (i.e.

trainers and

participants) to be all in one place/time was problematic due to the prison regime;

- Competing priorities

for prisoners led to high rate of refusal to

participate;

- Limited time

availability of staff, need

to escort prisoners to

groups

- From an individual perspective, group

sessions were not always suitable for discussing emotionally charged issues related to overdose and loss in the prison setting;
- The theory-based DVD containing prisonspecific OD

information and informed by input from end-users has been disseminated to several prisons and jails as part of re-entry planning for soon-tobe-released inmates.
- Because of operational challenges, prisons adopted the community NNP training model of brief interventions, delivered in a one-toone format over 10-15 min and requiring only one member of staff to facilitate.

- The implementation of the NNP with the Scottish Prison Service has faced several challenges, which have been addressed through innovation and partnership across Scottish Prisons and the community-based programs, and has resulted in a "largely consistent model" across facilities. 
Table 1 Summary of Articles Included in Scoping Review of Opioid Overdose Prevention for Justice-Involved Populations (Continued)

\begin{tabular}{|c|c|c|c|c|c|}
\hline Study & Study Objectives & Study Design & Sample/Setting & Key Findings & Study Implications \\
\hline & & & & $\begin{array}{l}\text { having to practice basic } \\
\text { life support may have } \\
\text { been intimidating for } \\
\text { some in a group } \\
\text { setting. } \\
\text { - Limited awareness } \\
\text { among prison officers } \\
\text { regarding naloxone } \\
\text { led to lack of follow- } \\
\text { through in placing it } \\
\text { with prisoner } \\
\text { possessions for } \\
\text { collection at discharge } \\
\text { - } 63 \text { male and } 6 \text { female } \\
\text { prisoners completed } \\
\text { the Scottish Drugs } \\
\text { Forum naloxone peer } \\
\text { education training in } 4 \\
\text { facilities } \\
\text { - Initiated a program for } \\
\text { providing prison } \\
\text { officers with naloxone } \\
\text { training in order to } \\
\text { intervene in an } \\
\text { overdose emergency, } \\
\text { rather than waiting for } \\
\text { health professionals }\end{array}$ & \\
\hline $\begin{array}{l}\text { Pearce, } \\
\text { Mathany, } \\
\text { Rothon, Kuo, \& } \\
\text { Buxton, } 2019 \\
{[35]}\end{array}$ & $\begin{array}{l}\text { To understand how the } \\
\text { THN program is } \\
\text { implemented in two } \\
\text { pilot correctional } \\
\text { facilities in order to } \\
\text { identify areas for } \\
\text { program improvement } \\
\text { and inform the } \\
\text { expansion of the } \\
\text { program to other } \\
\text { correctional facilities in } \\
\text { Canada. }\end{array}$ & $\begin{array}{l}\text { Focus groups and } \\
\text { interview }\end{array}$ & $\begin{array}{l}\text { Two focus groups ( } n= \\
8 \text { ) and one individual } \\
\text { interview with } \\
\text { healthcare staff who } \\
\text { were involved in } \\
\text { implementing THN } \\
\text { programs in } 2 \\
\text { correctional facilities in } \\
\text { British Columbia, } \\
\text { Canada }\end{array}$ & $\begin{array}{l}\text { - Barriers to "train the } \\
\text { trainer' program } \\
\text { included: lack of } \\
\text { capacity, including } \\
\text { time and staff } \\
\text { resources, to conduct } \\
\text { a thorough train-the- } \\
\text { trainer program; } \\
\text { competing healthcare } \\
\text { priorities and high } \\
\text { workloads since the } \\
\text { immediate healthcare } \\
\text { needs of persons in } \\
\text { custody took priority } \\
\text { over the THN } \\
\text { program; rotating } \\
\text { shifts that made } \\
\text { scheduling sessions } \\
\text { difficult } \\
\text { - Need to pay off-duty } \\
\text { healthcare staff to } \\
\text { participate in } \\
\text { additional group train- } \\
\text { the-trainer sessions } \\
\text { was a financial and } \\
\text { logistical burden } \\
\text { - Challenges of } \\
\text { connecting } \\
\text { participants to } \\
\text { community harm } \\
\text { reduction resources } \\
\text { following release } \\
\text { - Need for "whole } \\
\text { systems approach" } \\
\text { that includes support } \\
\text { from management } \\
\text { and other correctional } \\
\text { staff }\end{array}$ & $\begin{array}{l}\text { - The implementation } \\
\text { of the pilot program } \\
\text { faced several logistical } \\
\text { challenges but has the } \\
\text { potential for improved } \\
\text { prison population } \\
\text { engagement and } \\
\text { awareness of the } \\
\text { program; } \\
\text { - Findings suggest that } \\
\text { successful program } \\
\text { implementation } \\
\text { requires adapting } \\
\text { resources to the needs } \\
\text { of incarcerated } \\
\text { populations and } \\
\text { facility operations. }\end{array}$ \\
\hline
\end{tabular}


Table 1 Summary of Articles Included in Scoping Review of Opioid Overdose Prevention for Justice-Involved Populations (Continued)

\begin{tabular}{|c|c|c|c|c|c|}
\hline Study & Study Objectives & Study Design & Sample/Setting & Key Findings & Study Implications \\
\hline $\begin{array}{l}\text { Sondhi, Ryan, \& } \\
\text { Day, } 2016 \text { [36] }\end{array}$ & $\begin{array}{l}\text { To assess potential } \\
\text { barriers and challenges } \\
\text { to the implementation } \\
\text { of THN in prison. }\end{array}$ & $\begin{array}{l}\text { Qualitative interviews; } \\
\text { focus groups; } \\
\text { document review }\end{array}$ & $\begin{array}{l}\text { Four focus groups with } \\
\text { male prisoners who } \\
\text { participated in a THN } \\
\text { program }(n=26) \text {; } \\
\text { interviews with strategic } \\
\text { and operational prison } \\
\text { staff ( } n=17) \text { sampled } \\
\text { from } 10 \text { prisons within } \\
\text { one region in England }\end{array}$ & 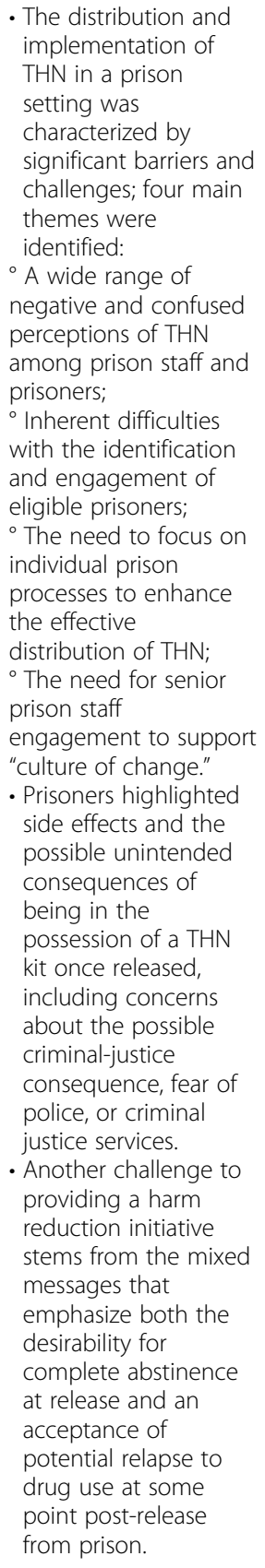 & $\begin{array}{l}\text { - Successful } \\
\text { implementation of } \\
\text { THN within prison } \\
\text { requires a 'whole } \\
\text { system' approach that } \\
\text { addresses negative } \\
\text { staff perceptions as } \\
\text { well as clear processes } \\
\text { to ensure eligible } \\
\text { prisoners are trained } \\
\text { and given access to } \\
\text { the THN kits. } \\
\text { - It is insufficient for } \\
\text { prisons to merely offer } \\
\text { training and distribute } \\
\text { kits to opiate-using } \\
\text { prisoners without } \\
\text { conducting a more } \\
\text { enhanced planning } \\
\text { and preparation } \\
\text { process. } \\
\text { - Two main } \\
\text { components must be } \\
\text { addressed: } \\
\text { o Need to develop a } \\
\text { detailed mapping of } \\
\text { prison processes and } \\
\text { including fears about } \\
\text { use in the community } \\
\text { and its side effects } \\
\text { prison staff establish } \\
\text { local processes to } \\
\text { identify eligible } \\
\text { prisoners and intervene } \\
\text { at the most effective } \\
\text { point in their } \\
\text { incarceration. } \\
\text { of Need to incorporate a } \\
\text { more nuanced } \\
\text { consideration of the } \\
\text { beliefs and perceptions } \\
\text { the effective } \\
\text { instion of THN } \\
\text { andison setting, }\end{array}$ \\
\hline $\begin{array}{l}\text { Zucker, Annucci, } \\
\text { Stancliff, \& } \\
\text { Catania, } 2015 \\
\text { [37] }\end{array}$ & $\begin{array}{l}\text { To describe a pilot } \\
\text { program to provide } \\
\text { training in OD } \\
\text { prevention and } \\
\text { naloxone to all } \\
\text { prisoners as they re- } \\
\text { enter the community. }\end{array}$ & $\begin{array}{l}\text { Qualitative: } \\
\text { Program description }\end{array}$ & $\begin{array}{l}\text { Minimum-security } \\
\text { correctional facility in } \\
\text { New York }\end{array}$ & $\begin{array}{l}\text { - A pilot at a minimum- } \\
\text { security correctional } \\
\text { facility in New York } \\
\text { City was initiated in } \\
\text { February 2015. Harm } \\
\text { Reduction Coalition } \\
\text { staff trained inmates in } \\
\text { the use of naloxone, } \\
\text { as well as prison staff } \\
\text { to provide the } \\
\text { trainings. } \\
\text { - By September } 2015,\end{array}$ & $\begin{array}{l}\text { - The OD prevention } \\
\text { program was } \\
\text { implemented through } \\
\text { collaboration between } \\
\text { state corrections and } \\
\text { community providers, } \\
\text { and has been } \\
\text { expanded to train } \\
\text { parole officers. } \\
\text { - Acceptance of the } \\
\text { program has been } \\
\text { augmented by the }\end{array}$ \\
\hline
\end{tabular}


Table 1 Summary of Articles Included in Scoping Review of Opioid Overdose Prevention for Justice-Involved Populations (Continued)

\begin{tabular}{|c|c|c|c|c|c|}
\hline Study & Study Objectives & Study Design & Sample/Setting & Key Findings & Study Implications \\
\hline & & & & $\begin{array}{l}\text { more than } 700 \\
\text { inmates had been } \\
\text { trained at one facility; } \\
\text { about } 200 \text { had } \\
\text { received kits. The } \\
\text { numbers of inmates } \\
\text { taking kits at release } \\
\text { increased each month, } \\
\text { suggesting growing } \\
\text { acceptance of the } \\
\text { program. } \\
\text { - Training was initiated } \\
\text { in two other } \\
\text { correctional facilities } \\
\text { and were scheduled at } \\
\text { other facilities. } \\
\text { - In addition, a } \\
\text { community-based } \\
\text { organization in the } \\
\text { region is training } \\
\text { family members and } \\
\text { friends of incarcerated } \\
\text { individuals and } \\
\text { equipping them with } \\
\text { naloxone free of } \\
\text { charge. } \\
\text { - The state Dept. of } \\
\text { Corrections } \\
\text { established a } \\
\text { statewide standing } \\
\text { order, in conjunction } \\
\text { with the Department } \\
\text { of Health, which } \\
\text { enables DOC nursing } \\
\text { staff to administer } \\
\text { naloxone by injection } \\
\text { to any inmate, staff or } \\
\text { visitor suspected of an } \\
\text { OD without first } \\
\text { obtaining a physician } \\
\text { order }\end{array}$ & $\begin{array}{l}\text { fact that many } \\
\text { corrections staff and } \\
\text { parole officers } \\
\text { recognize the need for } \\
\text { naloxone in their } \\
\text { communities. }\end{array}$ \\
\hline
\end{tabular}

Participant Overdose Risk: Temporal patterns in opioid overdose following release from prison or jail; participant characteristics and environmental factors associated with opioid overdose; interactions with service providers and settings prior to overdose

Alex, Weiss, Kaba, Rosner, Lee, Lim,

Venters, \& MacDonald, 2017 [38]
To understand postrelease death by matching electronic health records from incarcerated individuals with vital statistics records
Secondary analysis of records data weeks of release from
jail between 2011 and 2012 in New York City
- Mean no. of days to death was 20; 73\% died within 28 days of release; post-release all-cause mortality rate was 5.89 per 1000 PY

- Causes of death: $37 \%$ opioid overdose, $8.5 \%$ other drug overdose, $25 \%$ chronic disease, $20 \%$ assaultive trauma, 8.5\% trauma related to unintentional injury, suicide, or unspecified.

. $77 \%$ of those who died from opioid overdose had a history of prior overdose or opioid detoxification

- $14 \%$ were released with methadone dose; $50 \%$ had been referred to opioid
- Patient-centered history taking is necessary as many individuals do not disclose prior drug use history

- More aggressive linkage to opioid treatment programs is needed

- Expansion of access to buprenorphine and distribution of naloxone at release from jail are needed for overdose prevention. 
Table 1 Summary of Articles Included in Scoping Review of Opioid Overdose Prevention for Justice-Involved Populations (Continued)

\begin{tabular}{|c|c|c|c|c|c|}
\hline Study & Study Objectives & Study Design & Sample/Setting & Key Findings & Study Implications \\
\hline & & & & $\begin{array}{l}\text { treatment within the } \\
\text { community at release }\end{array}$ & \\
\hline $\begin{array}{l}\text { Andersson, } \\
\text { Håkansson, } \\
\text { Krantz, \& } \\
\text { Johnson, } 2020 \\
\text { [39] }\end{array}$ & $\begin{array}{l}\text { To investigate fatal } \\
\text { opioid intoxications in } \\
\text { southern Sweden } \\
\text { among people with a } \\
\text { history of illicit drug } \\
\text { use. The purpose of the } \\
\text { study is: (1) to survey } \\
\text { the deceased } \\
\text { individuals' contact with } \\
\text { care-providing } \\
\text { authorities during the } \\
\text { year prior to death; and } \\
\text { (2) to analyze } \\
\text { differences in their } \\
\text { clinical picture, relating } \\
\text { to which opioids } \\
\text { caused their deaths. }\end{array}$ & $\begin{array}{l}\text { Secondary analysis of } \\
\text { records data }\end{array}$ & $\begin{array}{l}180 \text { opioid-related } \\
\text { deaths where the cause } \\
\text { of death was } \\
\text { intoxication due to the } \\
\text { intake of heroin, } \\
\text { methadone, } \\
\text { buprenorphine, or } \\
\text { fentanyl in Sweden }\end{array}$ & $\begin{array}{l}\text { - } 89 \% \text { of the deceased } \\
\text { individuals had been } \\
\text { in contact with one or } \\
\text { more care-providing } \\
\text { authorities in the year } \\
\text { prior to death: } \\
\text { - } 75 \% \text { had been in } \\
\text { contact with health } \\
\text { care services } \\
{ }^{\circ} 69 \% \text { with the social } \\
\text { services } \\
\text {-28\% with the Prison } \\
\text { and Probation Service } \\
\text {-23\% had been } \\
\text { enrolled in OST } \\
\text { - Sedatives were } \\
\text { present in more than } \\
80 \% \text { of the cases. } \\
\text { - Individuals whose } \\
\text { deaths were } \\
\text { buprenorphine-related } \\
\text { had been in contact } \\
\text { with the social services } \\
\text { to a significantly lesser } \\
\text { extent during the year } \\
\text { prior to death. }\end{array}$ & $\begin{array}{l}\text { - Individuals who died } \\
\text { from opioid-related } \\
\text { intoxication had } \\
\text { extensive contact with } \\
\text { care-providing } \\
\text { authorities, thus } \\
\text { providing numerous } \\
\text { opportunities to } \\
\text { intervene with } \\
\text { preventive and other } \\
\text { interventions. } \\
\text { - Developing a broader } \\
\text { understanding of the } \\
\text { lives and deaths of } \\
\text { opioid users is } \\
\text { essential for the } \\
\text { development and } \\
\text { provision of effective } \\
\text { treatment and harm } \\
\text { reduction } \\
\text { interventions. }\end{array}$ \\
\hline $\begin{array}{l}\text { Binswanger, } \\
\text { Nowels, Corsi, } \\
\text { Glanz, Long, } \\
\text { Booth, \& Steiner, } \\
2012 \text { [40] }\end{array}$ & $\begin{array}{l}\text { To understand the drug } \\
\text { use experiences, } \\
\text { perceptions of overdose } \\
\text { risk, and experiences } \\
\text { with overdose among } \\
\text { former prisoners }\end{array}$ & Survey & $\begin{array}{l}29 \text { former prison } \\
\text { inmates recruited } \\
\text { within } 2 \text { months of } \\
\text { release from a } \\
\text { community health } \\
\text { center, an urgent care } \\
\text { center, and addiction } \\
\text { treatment centers, as } \\
\text { well as by snowball } \\
\text { sampling, in Denver, } \\
\text { Colorado }\end{array}$ & $\begin{array}{l}\text { The following themes } \\
\text { emerged: } \\
\text { - Relapse to drugs and } \\
\text { alcohol occurred in a } \\
\text { context of poor social } \\
\text { support, medical co- } \\
\text { morbidity and } \\
\text { inadequate economic } \\
\text { resources; } \\
\text { - Former inmates } \\
\text { experienced } \\
\text { ubiquitous exposure } \\
\text { to drugs in their living } \\
\text { environments posing } \\
\text { a risk of relapse; } \\
\text { - Intentional overdose } \\
\text { was considered "a way } \\
\text { out" given situational } \\
\text { stressors, and } \\
\text { accidental overdose } \\
\text { was perceived as } \\
\text { related to decreased } \\
\text { tolerance; and } \\
\text { - Protective factors } \\
\text { included structured } \\
\text { drug treatment } \\
\text { programs, spirituality/ } \\
\text { religion, community- } \\
\text { based resources } \\
\text { (including self-help } \\
\text { groups), and family. }\end{array}$ & $\begin{array}{l}\text { - Interventions to } \\
\text { prevent overdose after } \\
\text { release from prison } \\
\text { may benefit from } \\
\text { including structured } \\
\text { treatment with } \\
\text { gradual transition to } \\
\text { the community, } \\
\text { enhanced protective } \\
\text { factors, and reductions } \\
\text { of environmental } \\
\text { triggers to use drugs. }\end{array}$ \\
\hline $\begin{array}{l}\text { Binswanger, } \\
\text { Stern, } \\
\text { Yamashita, } \\
\text { Mueller, Baggett, } \\
\text { \& Blatchford, } \\
2016[41]\end{array}$ & $\begin{array}{l}\text { To identify risk and } \\
\text { protective factors for } \\
\text { all-cause and accidental } \\
\text { poisoning (overdose) } \\
\text { death among } \\
\text { individuals following }\end{array}$ & $\begin{array}{l}\text { Nested case-control } \\
\text { study of people } \\
\text { released from prison }\end{array}$ & $\begin{array}{l}\text { Cases ( } 699 \text { all-cause } \\
\text { deaths, } 88 \text { were among } \\
\text { women; and } 196 \\
\text { additional overdose } \\
\text { deaths, } 76 \text { were among } \\
\text { women) between } 1999\end{array}$ & $\begin{array}{l}\text { - Key independent risk } \\
\text { factors for all-cause } \\
\text { mortality included } \\
\text { homelessness (OR }= \\
\text { 1.53, } 95 \% \mathrm{Cl}=1.06 \\
\text { 2.23), IDU (OR }=1.54\end{array}$ & $\begin{array}{l}\text { - Injection drug use and } \\
\text { SUD are risk factors for } \\
\text { death after release } \\
\text { from prison. } \\
\text { - In-prison SUD } \\
\text { treatment services }\end{array}$ \\
\hline
\end{tabular}


Table 1 Summary of Articles Included in Scoping Review of Opioid Overdose Prevention for Justice-Involved Populations (Continued)

\begin{tabular}{|c|c|c|c|c|c|}
\hline Study & Study Objectives & Study Design & Sample/Setting & Key Findings & Study Implications \\
\hline & release from prison & & $\begin{array}{l}\text { and } 2009 \text { matched 1: } 1 \\
\text { to controls on sex, age } \\
\text { and year of release } \\
\text { from Washington State } \\
\text { Department of } \\
\text { Corrections }\end{array}$ & 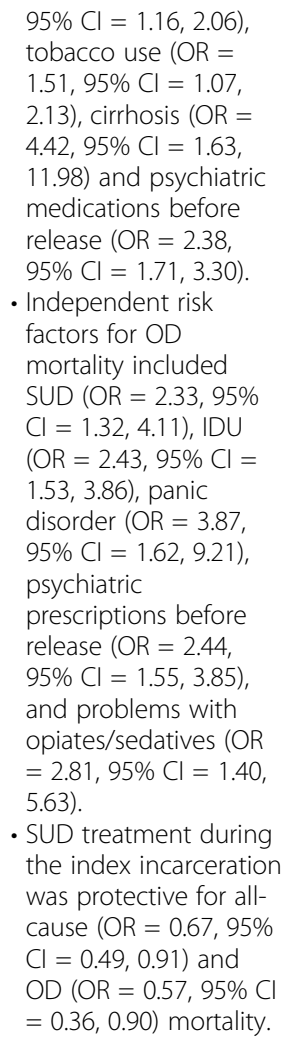 & may reduce the risk. \\
\hline $\begin{array}{l}\text { Binswanger, } \\
\text { Nguyen, } \\
\text { Morenoff, Xu, \& } \\
\text { Harding, } 2020 \\
\text { [42] }\end{array}$ & $\begin{array}{l}\text { To examine the } \\
\text { associations between } \\
\text { characteristics of justice- } \\
\text { involved individuals } \\
\text { regarding use patterns, } \\
\text { drug convictions and } \\
\text { supervision setting, and } \\
\text { overdose mortality. }\end{array}$ & $\begin{array}{l}\text { Secondary analysis of } \\
\text { records data }\end{array}$ & $\begin{array}{l}\text { 140,266 individuals with } \\
\text { a history of criminal } \\
\text { justice involvement and } \\
\text { OUD from } 2003 \text { to } 2006 \\
\text { in Michigan }\end{array}$ & 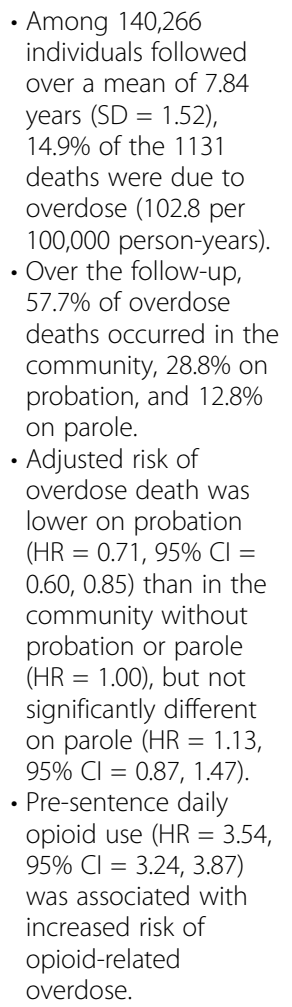 & $\begin{array}{l}\text { - Given the absolute or } \\
\text { relative risk of opioid- } \\
\text { related overdose } \\
\text { among justice- } \\
\text { involved individuals, } \\
\text { parole, probation and } \\
\text { community settings } \\
\text { are appropriate } \\
\text { settings for enhanced } \\
\text { overdose prevention } \\
\text { interventions. } \\
\text { - Ensuring that } \\
\text { individuals with pre- } \\
\text { sentence OUD have } \\
\text { access to harm } \\
\text { reduction and drug } \\
\text { treatment services } \\
\text { may help to prevent } \\
\text { overdose among } \\
\text { people involved with } \\
\text { the CJS. }\end{array}$ \\
\hline
\end{tabular}


Table 1 Summary of Articles Included in Scoping Review of Opioid Overdose Prevention for Justice-Involved Populations (Continued)

\begin{tabular}{|c|c|c|c|c|c|}
\hline Study & Study Objectives & Study Design & Sample/Setting & Key Findings & Study Implications \\
\hline & & & & $\begin{array}{l}\text { - Drug possession }(\mathrm{HR}= \\
1.11,95 \% \mathrm{Cl}=0.93, \\
1.31) \text { and delivery } \\
\text { convictions ( } \mathrm{HR}=0.92, \\
95 \% \mathrm{Cl}=0.77,1.09) \\
\text { were not significantly } \\
\text { associated with } \\
\text { overdose mortality. }\end{array}$ & \\
\hline $\begin{array}{l}\text { Bird, } \\
\text { Fischbacher, } \\
\text { Graham, \& } \\
\text { Fraser, } 2015 \text { [43] }\end{array}$ & $\begin{array}{l}\text { To assess whether the } \\
\text { introduction of a } \\
\text { prison-based OST policy } \\
\text { was associated with a } \\
\text { reduction in drug- } \\
\text { related deaths (DRD) } \\
\text { within } 14 \text { days after } \\
\text { prison release. }\end{array}$ & $\begin{array}{l}\text { Time series analysis of } \\
\text { pre/post intervention }\end{array}$ & $\begin{array}{l}\text { Linkage of Scotland's } \\
\text { prisoner database with } \\
\text { death registrations to } \\
\text { compare periods before } \\
\text { (1996-2002) and after } \\
\text { (2003-07) prison-based } \\
\text { OST was introduced. }\end{array}$ & $\begin{array}{l}\text { - Before prison-based } \\
\text { OST (1996-2002), } 305 \\
\text { DRDs occurred in the } \\
12 \text { weeks after } 80,200 \\
\text { qualifying releases, } 3.8 \\
\text { per } 1000 \text { releases; of } \\
\text { these, } 175 \text { (57\%) } \\
\text { occurred in the first } 14 \\
\text { days. } \\
\text { - After the introduction } \\
\text { of prison-based OST } \\
\text { (2003-07), } 154 \text { DRDs } \\
\text { occurred in the } 12 \\
\text { weeks after } 70,317 \\
\text { qualifying releases, a } \\
\text { significantly reduced } \\
\text { rate of } 2.2 \text { per } 1000 \\
\text { releases. } \\
\text { - There was no change } \\
\text { in the proportion that } \\
\text { occurred in the first } 14 \\
\text { days, either for all } \\
\text { DRDs or for opioid- } \\
\text { related DRDs. }\end{array}$ & $\begin{array}{l}\text { - Following the } \\
\text { introduction of a } \\
\text { prison-based OST } \\
\text { policy in Scotland, the } \\
\text { rate of drug-related } \\
\text { deaths in the } 12 \\
\text { weeks following } \\
\text { release fell by two- } \\
\text { fifths. } \\
\text { - However, the } \\
\text { proportion of deaths } \\
\text { that occurred in the } \\
\text { first } 14 \text { days did not } \\
\text { change appreciably, } \\
\text { suggesting that in- } \\
\text { prison OST does not } \\
\text { reduce early deaths } \\
\text { after release. }\end{array}$ \\
\hline $\begin{array}{l}\text { Bukten, Stavseth, } \\
\text { Skurtveit, } \\
\text { Tverdal, Strang, } \\
\text { \& Clausen, } 2017 \\
\text { [44] }\end{array}$ & $\begin{array}{l}\text { To estimate and } \\
\text { compare overdose } \\
\text { death rates at time } \\
\text { intervals after prison } \\
\text { release and to estimate } \\
\text { the effect on overdose } \\
\text { death rates over } \\
\text { calendar time over a } \\
15 \text {-year observation } \\
\text { period. }\end{array}$ & $\begin{array}{l}\text { Secondary analysis of } \\
\text { records data from } \\
\text { Norwegian Prison } \\
\text { Registry and Norwegian } \\
\text { Cause of Death Registry }\end{array}$ & $\begin{array}{l}\text { All individuals released } \\
\text { from prison in Norway } \\
\text { between 1/1/2000 and } \\
12 / 31 / 2014 \text {; the final } \\
\text { sample comprised } 91 \text {, } \\
090 \text { former prisoners, } \\
\text { released 150,090 times }\end{array}$ & $\begin{array}{l}\text { - Overdose deaths } \\
\text { accounted for } 85 \% \text { ( } n \\
=123 \text { ) of all deaths } \\
\text { during the first week } \\
\text { following release ( } n= \\
\text { 145), with a peak in } \\
\text { the } 2 \text { days } \\
\text { immediately following } \\
\text { release. } \\
\text { - Compared with week } \\
\text { 1, the risk of overdose } \\
\text { death was reduced by } \\
\text { more than half during } \\
\text { week } 2 \text { and to one- } \\
\text { fifth in weeks } 3-4 \text {. } \\
\text { - The risk of overdose } \\
\text { mortality during the } \\
\text { first } 6 \text { months post- } \\
\text { release was almost } \\
\text { doubled in } 2000-04 \\
\text { compared with } 2005- \\
09 . \\
\text { - The risk of overdose } \\
\text { death was highest for } \\
\text { those incarcerated for } \\
3-12 \text { months } \\
\text { compared with those } \\
\text { who were incarcerated } \\
\text { for shorter or longer } \\
\text { periods, and recidivism } \\
\text { was associated with } \\
\text { risk of overdose death. }\end{array}$ & $\begin{array}{l}\text { - There is an elevated } \\
\text { risk of death from } \\
\text { drug overdose among } \\
\text { individuals released } \\
\text { from Norwegian } \\
\text { prisons, peaking in the } \\
\text { first week, with the } \\
\text { greatest risk for those } \\
\text { serving 3-12 months } \\
\text { compared with shorter } \\
\text { or longer periods. } \\
\text { - Reductions in } \\
\text { overdose mortality } \\
\text { over time may be } \\
\text { related to increases in } \\
\text { participation in OAT } \\
\text { and changes in } \\
\text { patterns of drug } \\
\text { consumption } \\
\text { - Collaboration among } \\
\text { correctional services, } \\
\text { drug treatment } \\
\text { services, and social } \\
\text { services is necessary to } \\
\text { facilitate a safe release } \\
\text { from prison. } \\
\text { - Provision of effective } \\
\text { treatment, such as } \\
\text { opioid maintenance } \\
\text { treatment, as well as } \\
\text { of naloxone along } \\
\text { with harm reduction } \\
\text { and social } \\
\text { reintegration support }\end{array}$ \\
\hline
\end{tabular}


Table 1 Summary of Articles Included in Scoping Review of Opioid Overdose Prevention for Justice-Involved Populations (Continued)

\begin{tabular}{ll}
\hline Study & Study Objectives \\
\hline & \\
& \\
& \\
Cepeda, Vetrova, & To understand the \\
Lyubimova, & context of the post- \\
Levina, Heimer, & release risk environment \\
\& Niccolai, 2015 & among formerly \\
[45] & incarcerated PWID in \\
& $\begin{array}{l}\text { Russia regarding how } \\
\text { these risks relate to } \\
\text { reentry, relapse to } \\
\text { injection opioid use, } \\
\text { and overdose. }\end{array}$
\end{tabular}

Forsyth, Carroll, Lennox, Kinner, \& 2017 [46]
Semi-structured in-

depth interviews and overdose.

Study Design

25 PWID who had been
incarcerated within the
past 2 years who were
recruited from street
outreach $(n=20)$ and a
drug treatment center
$(n=5)$ in St. Petersburg,
Russia

Emergent themes related to the postrelease environment included financial instability, negative interactions with police, return to a drug-using community, and reuniting with drug using peers.

- Almost half the sample had an opioid overdose after release with the median time to overdose of 30 days after release.

- Many respondents relapsed to opioid use immediately after release; others who relapsed weeks or months after their release expressed more motivation to resist.

- Alcohol or stimulant use often preceded opioid relapse; alcohol use often preceded opioid overdose.

To estimate the incidence and identify risk factors for mortality in adults released from prisons in Queensland, Australia
Prospective cohort study, linking baseline survey data with a national death register over up to 4.7 years in the community
1320 adults recruited in prisons within 6 weeks of expected release, between August 2008 Queensland, Australia and July 2010 in
- The rate of mortality in the cohort was higher than in the age- and sex-matched general population of Queensland for all causes (SMR $=4.0$ $95 \% \mathrm{Cl}=2.9-5.4]$ and drug-related causes (SMR $=32,95 \% \mathrm{Cl}=$ 19-55)

- In a multivariable model, adjusting for age, sex and Indigenous status, factors associated with increased mortality risk included expecting to have average or better funds available on release $(\mathrm{AHR}=2.9$ $99 \% \mathrm{Cl}=1.2-7.1)$, poor mental health (AHR = 2.6,99\% Cl = 1.1-6.1) and selfreported life-time history of overdose $(\mathrm{AHR}=2.5,99 \% \mathrm{Cl}=$ 1.04-6.2).
Study Implications

in correctional settings is essential to reducing overdose deaths postrelease among former inmates.

- Future post-release interventions in Russia should effectively link PWID to social, medical, and harm reduction services.

- Particular attention should be focused on helping former inmates find employment

- Overdose prevention training prior to leaving prison should also cover the heightened risk of concomitant alcohol use.

- The study found that people released from prison in Queensland, Australia are at increased risk of death, particularly due to drug-related causes. - Those at greatest risk of death are characterized by poor physical and mental health and a history of risky substance use, including lifetime history of overdose. 
Table 1 Summary of Articles Included in Scoping Review of Opioid Overdose Prevention for Justice-Involved Populations (Continued)

\begin{tabular}{|c|c|c|c|c|c|}
\hline Study & Study Objectives & Study Design & Sample/Setting & Key Findings & Study Implications \\
\hline $\begin{array}{l}\text { Hacker, Jones, } \\
\text { Brink, Wilson, } \\
\text { Cherna, Dalton, } \\
\text { \& Hulsey, } 2018 \\
\text { [47] }\end{array}$ & $\begin{array}{l}\text { (1) To describe the } \\
\text { demographic } \\
\text { characteristics and the } \\
\text { opioid epidemic in } \\
\text { Allegheny County; } \\
\text { (2) To identify possible } \\
\text { points for intervention, } \\
\text { recognizing that } \\
\text { overdose decedents } \\
\text { may have used various } \\
\text { public human services } \\
\text { before their death; } \\
\text { (3) To determine the } \\
\text { temporal relationship } \\
\text { between overdose } \\
\text { mortality and } \\
\text { incarceration or the use } \\
\text { of mental health or } \\
\text { SUD services; } \\
\text { (4) To recommend } \\
\text { potentially beneficial } \\
\text { interventions. }\end{array}$ & $\begin{array}{l}\text { Secondary analysis of } \\
\text { records data }\end{array}$ & $\begin{array}{l}\text { Records of } 1399 \\
\text { individuals who died of } \\
\text { opioid overdoses from } \\
2008 \text { to } 2014 \text { who were } \\
\text { matched to records of } \\
\text { their premortem } \\
\text { incarcerations and use } \\
\text { of mental health and } \\
\text { SUD services in } \\
\text { Alleghany, PA }\end{array}$ & $\begin{array}{l}\text { - Of the } 1399 \\
\text { decedents, } 957 \text { (68.4\%) } \\
\text { had a public human } \\
\text { service encounter } \\
\text { before overdose } \\
\text { death. } \\
\text { - Of these } 957 \\
\text { decedents, } 531 \text { (55.5\%) } \\
\text { had ever been } \\
\text { incarcerated in the } \\
\text { county jail, } 616 \text { (64.4\%) } \\
\text { had ever used a } \\
\text { mental health service, } \\
\text { and } 702 \text { (73.4\%) had } \\
\text { ever used a substance } \\
\text { use disorder service. } \\
\text { - Of } 211 \text { ( } 22 \% \text { ) } \\
\text { decedents } \\
\text { incarcerated in the } \\
\text { year before their } \\
\text { overdose death, } 54 \\
\text { ( } 25.6 \% \text { ) overdosed } \\
\text { within } 30 \text { days of their } \\
\text { last release from jail. } \\
\text { - Of } 510 \text { decedents } \\
\text { using mental health } \\
\text { services in the year } \\
\text { before death, } 231 \\
\text { (45.3\%) overdosed } \\
\text { within } 30 \text { days of their } \\
\text { last use of the services. } \\
\text { - Of } 350 \text { decedents } \\
\text { using SuD services in } \\
\text { the year before their } \\
\text { overdose death, } 134 \\
\text { (38.3\%) overdosed } \\
\text { within } 30 \text { days of their } \\
\text { last use of the services. }\end{array}$ & $\begin{array}{l}\text { - The large number of } \\
\text { decedents who had } \\
\text { encounters with either } \\
\text { mental health or SUD } \\
\text { services close to the } \\
\text { time of their overdose } \\
\text { deaths suggests that } \\
\text { these encounters may } \\
\text { be an important } \\
\text { opportunity for } \\
\text { intervention. } \\
\text { - Effective screening } \\
\text { and brief intervention } \\
\text { procedures, especially } \\
\text { as part of mental } \\
\text { health treatment, can } \\
\text { identify active drug } \\
\text { use and potential } \\
\text { overdose risk. } \\
\text { - Merging data on } \\
\text { overdose mortality } \\
\text { with data on use of } \\
\text { public human services } \\
\text { can be a useful } \\
\text { strategy to identify } \\
\text { trends in, and factors } \\
\text { contributing to, the } \\
\text { opioid epidemic; to } \\
\text { target interventions; } \\
\text { and to stimulate } \\
\text { collaboration among } \\
\text { public health and } \\
\text { community providers } \\
\text { to address the } \\
\text { epidemic } \\
\end{array}$ \\
\hline $\begin{array}{l}\text { Keen, Young, } \\
\text { Borschmann, \& } \\
\text { Kinner, } 2020 \text { [48] }\end{array}$ & $\begin{array}{l}\text { To determine the } \\
\text { incidence, predictors } \\
\text { and clinical } \\
\text { characteristics of NFOD } \\
\text { following release from } \\
\text { prison. }\end{array}$ & $\begin{array}{l}\text { Secondary analysis of } \\
\text { records data }\end{array}$ & $\begin{array}{l}1307 \text { adults who had } \\
\text { participated in RCT of a } \\
\text { case-management } \\
\text { intervention to increase } \\
\text { engagement with } \\
\text { primary care and } \\
\text { mental healthcare after } \\
\text { release from prison in } \\
\text { Queensland, Australia }\end{array}$ & $\begin{array}{l}\text { - Approximately } 8 \% \text { of } \\
\text { participants had at } \\
\text { least one NFOD } \\
\text { during a median of } 2.9 \\
\text { years of follow-up } \\
\text { - The crude incidence } \\
\text { rate (IR) of NFOD was } \\
47.6 \text { (95\% Cl 41.1-55.0) } \\
\text { per } 1000 \text { person-years } \\
\text { and was highest in } \\
\text { the first } 14 \text { days after } \\
\text { release from prison (IR } \\
\text { = } 296 \text { per } 1000 \\
\text { person-years, } 95 \% \text { CI } \\
206-426 \text { ). } \\
\text { - In multivariate } \\
\text { analyses, NFOD after } \\
\text { release from prison } \\
\text { was positively } \\
\text { associated with a } \\
\text { recent history of SUD, } \\
\text { dual diagnosis of } \\
\text { mental illness and } \\
\text { SUD, lifetime history of } \\
\text { injecting drug use, } \\
\text { lifetime history of } \\
\text { NFOD, being } \\
\text { dispensed }\end{array}$ & $\begin{array}{l}\text { - Individuals released } \\
\text { from prison are at } \\
\text { high risk of non-fatal } \\
\text { overdose, particularly } \\
\text { in the first } 14 \text { days } \\
\text { after release. } \\
\text { - Providing coordinated } \\
\text { transitional care } \\
\text { between prison and } \\
\text { the community is } \\
\text { needed to reduce the } \\
\text { risk of overdose. }\end{array}$ \\
\hline
\end{tabular}


Table 1 Summary of Articles Included in Scoping Review of Opioid Overdose Prevention for Justice-Involved Populations (Continued)

\begin{tabular}{|c|c|c|c|c|c|}
\hline Study & Study Objectives & Study Design & Sample/Setting & Key Findings & Study Implications \\
\hline & & & & $\begin{array}{l}\text { benzodiazepines after } \\
\text { release, a shorter index } \\
\text { incarceration, and low } \\
\text { perceived social } \\
\text { support. } \\
\text { - } 33 \% \text { of those who } \\
\text { experienced an NFOD } \\
\text { after index release had } \\
\text { not previously } \\
\text { overdosed } \\
\text { - The risk of NFOD was } \\
\text { lower for people with } \\
\text { high-risk alcohol use } \\
\text { and while incarcerated }\end{array}$ & \\
\hline $\begin{array}{l}\text { Kinner, Milloy, } \\
\text { Wood, Qi, } \\
\text { Zhang, \& Kerr, } \\
2012 \text { [49] }\end{array}$ & $\begin{array}{l}\text { To identify risk and } \\
\text { protective factors for } \\
\text { NFOD among a cohort } \\
\text { of illicit drug users in } \\
\text { Vancouver, Canada, } \\
\text { according to recent } \\
\text { incarceration. }\end{array}$ & $\begin{array}{l}\text { Prospective cohort } \\
\text { study }\end{array}$ & $\begin{array}{l}2515 \text { community- } \\
\text { recruited illicit drug } \\
\text { users followed from } \\
1996 \text { to } 2010 \text { in } \\
\text { Vancouver, Canada }\end{array}$ & $\begin{array}{l}\text { - One third of } \\
\text { participants ( } n=829 \text {, } \\
33.0 \% \text { ) reported at } \\
\text { least one recent } \\
\text { NFOD; those recently } \\
\text { incarcerated were } \\
\text { significantly more likely } \\
\text { to report recent NFOD } \\
\text { (OR = 2.13, 95\% Cl } \\
\text { 1.89-2.40, } p<0.001 \text { ). } \\
\text { - Among those recently } \\
\text { incarcerated, risk } \\
\text { factors independently } \\
\text { and positively } \\
\text { associated with NFOD } \\
\text { included daily use of } \\
\text { heroin, } \\
\text { benzodiazepines, } \\
\text { cocaine or } \\
\text { methamphetamine, } \\
\text { binge drug use, public } \\
\text { injecting and previous } \\
\text { NFOD. } \\
\text { - Older age, methadone } \\
\text { maintenance } \\
\text { treatment, and HIV+ } \\
\text { status were protective } \\
\text { against NFOD. }\end{array}$ & $\begin{array}{l}\text { - There is an urgent } \\
\text { need to develop and } \\
\text { implement evidence- } \\
\text { based preventive } \\
\text { interventions for ex- } \\
\text { prisons that target } \\
\text { those with modifiable } \\
\text { risk factors. }\end{array}$ \\
\hline $\begin{array}{l}\text { Larochelle, } \\
\text { Bernstein, } \\
\text { Bernson, Land, } \\
\text { Stopka, Rose, } \\
\text { Bharel, } \\
\text { Liebschutz, \& } \\
\text { Walley, 2019 } \\
{[50]}\end{array}$ & $\begin{array}{l}\text { To identify potential } \\
\text { touchpoints for } \\
\text { intervention with } \\
\text { individuals at risk of } \\
\text { overdose, including } \\
\text { those within the CJS. }\end{array}$ & $\begin{array}{l}\text { Secondary analysis of } \\
\text { records data }\end{array}$ & $\begin{array}{l}\text { General population of } \\
\text { Massachusetts aged } 11 \\
\text { and older in } 2014 \text { with } \\
\text { non-missing data on } \\
\text { sex and age; } N=6,717, \\
390 ; \text { analysis of } \\
\text { individuals who died } \\
\text { from opioid overdose } \\
\text { from } 2011 \text { to } 2015\end{array}$ & $\begin{array}{l}\text { - Past 12-month } \\
\text { exposure to any } \\
\text { touchpoint was } \\
\text { identified in } 2.7 \% \text { of } \\
\text { person-months and } \\
\text { for } 51.8 \% \text { of opioid } \\
\text { overdose deaths. } \\
\text { - Opioid overdose SMRs } \\
\text { were } 12.6 \text { (95\% Cl: } \\
\text { 11.1, 14.1) for opioid } \\
\text { prescription and } 68.4 \\
\text { (95\% Cl: } 62.4,74.5) \text { for } \\
\text { critical encounter } \\
\text { touchpoints. } \\
\text { - SMR = 30.0 (95\% Cl: } \\
24.8,35.3 \text { ) for } \\
\text { individuals released } \\
\text { from prison or jail } \\
\text { - PAFs were 0.19 (95\% } \\
\text { Cl: 0.17, 0.21) for } \\
\text { opioid prescription } \\
\text { and 0.37 (95\% Cl: } 0.34 \text {, } \\
\text { 0.39) for critical } \\
\text { encounter }\end{array}$ & $\begin{array}{l}\text { - Medical care, public } \\
\text { health, and CJS } \\
\text { encounters could } \\
\text { serve as touchpoints } \\
\text { to identify and } \\
\text { intervene with } \\
\text { individuals at high-risk } \\
\text { of opioid overdose } \\
\text { death, although the } \\
\text { relative risk of opioid } \\
\text { overdose death and } \\
\text { proportion of deaths } \\
\text { that could be averted } \\
\text { at such touchpoints } \\
\text { are unknown }\end{array}$ \\
\hline
\end{tabular}


Table 1 Summary of Articles Included in Scoping Review of Opioid Overdose Prevention for Justice-Involved Populations (Continued)

\begin{tabular}{|c|c|c|c|c|c|}
\hline Study & Study Objectives & Study Design & Sample/Setting & Key Findings & Study Implications \\
\hline & & & & $\begin{array}{l}\text { touchpoints. } \\
\text { - Eight candidate } \\
\text { touchpoints were } \\
\text { associated with } \\
\text { increased risk of fatal } \\
\text { opioid overdose, and } \\
\text { collectively identified } \\
\text { more than half of all } \\
\text { opioid overdose deaths. }\end{array}$ & \\
\hline $\begin{array}{l}\text { Moore, Winter, } \\
\text { Indig, } \\
\text { Greenberg, \& } \\
\text { Kinner, } 2013 \text { [51] }\end{array}$ & $\begin{array}{l}\text { To estimate the } \\
\text { prevalence and } \\
\text { correlates of lifetime } \\
\text { NFOD among prisoners } \\
\text { in from two states in } \\
\text { Australia }\end{array}$ & $\begin{array}{l}\text { Secondary analyses of } \\
\text { cross-sectional surveys }\end{array}$ & $\begin{array}{l}2288 \text { adults in prison } \\
\text { that were included in } \\
\text { the } 2009 \text { New South } \\
\text { Wales (NSW) Inmate } \\
\text { Health Survey and the } \\
\text { Passports Study from } \\
\text { New South Wales and } \\
\text { Queensland, Australia }\end{array}$ & $\begin{array}{l}\text { - In both NSW and } \\
\text { Queensland, 23\% of } \\
\text { participants reported a } \\
\text { lifetime history of } \\
\text { NFOD and prisoners } \\
\text { with a history of IDU } \\
\text { use were significantly } \\
\text { more likely to report } \\
\text { lifetime NFOD. } \\
\text { - The lifetime } \\
\text { prevalence of NFOD } \\
\text { among prisoners with } \\
\text { a history of IDU was } \\
\text { significantly higher in } \\
\text { NSW than in } \\
\text { Queensland (44\% vs. } \\
\text { 35\%; } p \text { < 0.01). } \\
\text { - Independent } \\
\text { correlates of lifetime } \\
\text { NFOD were similar } \\
\text { across the two states } \\
\text { and included having } \\
\text { attempted suicide, } \\
\text { injected heroin or } \\
\text { other opioids. }\end{array}$ & $\begin{array}{l}\text { - The risk of NFOD } \\
\text { among prisoners with } \\
\text { a history of injecting } \\
\text { drug use is high. } \\
\text { - An understanding of } \\
\text { the risk factors for } \\
\text { NFOD in this } \\
\text { population can inform } \\
\text { targeted, evidence- } \\
\text { based interventions to } \\
\text { reduce this risk. }\end{array}$ \\
\hline $\begin{array}{l}\text { Pizzicato, Drake, } \\
\text { Domer-Shank, } \\
\text { Johnson, \& } \\
\text { Viner, 2018 [52] }\end{array}$ & $\begin{array}{l}\text { To determine overdose } \\
\text { mortality rates among } \\
\text { offenders after release } \\
\text { from the Philadelphia } \\
\text { jail system. }\end{array}$ & $\begin{array}{l}\text { Retrospective cohort } \\
\text { study linking } \\
\text { incarceration data with } \\
\text { OD fatality and death } \\
\text { records }\end{array}$ & $\begin{array}{l}82,780 \text { incarcerated } \\
\text { individuals released } \\
\text { from the criminal justice } \\
\text { system between } 2010 \\
\text { and } 2016 \text { in } \\
\text { Philadelphia; } 80.2 \% \\
\text { male }\end{array}$ & $\begin{array}{l}\text { - Of the sample, } 2522 \\
\text { (3\%) died from any } \\
\text { cause, of which } 33 \% \\
\text { died from OD } \\
\text { - Individuals released } \\
\text { from incarceration had } \\
\text { higher risk of OD } \\
\text { death compared to } \\
\text { the non-incarcerated } \\
\text { population (SMR: } 5.29 \text {, } \\
\text { 95\% Cl 4.93-5.65), and } \\
\text { risk was greatest } \\
\text { during the first } 2 \\
\text { weeks following } \\
\text { release (SMR: } 36.91, \\
\text { 95\% Cl: } 29.92-43.90) \text {. } \\
\text { - Among released } \\
\text { individuals, black, non- } \\
\text { Hispanic individuals } \\
\text { (HR: 0.17, 95\% Cl: } \\
\text { 0.14-0.19) and } \\
\text { Hispanic individuals } \\
\text { (HR: 0.41, 95\% Cl: } \\
\text { 0.34-0.50) were at } \\
\text { lower risk for OD than } \\
\text { white, non-Hispanic } \\
\text { individuals. } \\
\text { - Individuals released } \\
\text { with a serious mental } \\
\text { illness were at higher } \\
\text { risk of overdose (HR: } \\
\text { 1.54, 95\% Cl: } 1.27-\end{array}$ & $\begin{array}{l}\text { - Previously incarcerated } \\
\text { individuals are at high } \\
\text { risk of OD death } \\
\text { following release from } \\
\text { a local criminal justice } \\
\text { systems, especially in } \\
\text { the earliest weeks } \\
\text { following release. } \\
\text { - Prevention measures } \\
\text { including behavioral } \\
\text { health treatment and } \\
\text { referral and take-home } \\
\text { naloxone may reduce } \\
\text { overdose mortality } \\
\text { after release. }\end{array}$ \\
\hline
\end{tabular}


Table 1 Summary of Articles Included in Scoping Review of Opioid Overdose Prevention for Justice-Involved Populations (Continued)

\begin{tabular}{ll}
\hline Study & Study Objectives \\
\hline & \\
Ranapurwala, & To examine differences \\
Shanahan, & in rates of opioid \\
Alexandridis, & overdose death (OOD) \\
Proescholdbell, & between former North \\
Naumann, \& & Carolina (NC) inmates \\
Edwards, 2018 & and NC residents and \\
{$[53]$} & evaluate factors \\
& associated with post \\
& release OOD.
\end{tabular}

Study Design

Retrospective cohort study

release OOD.
Spittal, Forsyth, To identify modifiable Borschmann, risk and protective Young, \& Kinner, factors for external 2019 [54] cause and causespecific mortality after release from prison.
Secondary analysis of data from a retrospective cohort study and records data
572 inmates released from prison between 1994 and $2007(n=286$ cases, $n=286$ matched controls) in Queensland, Australia
229,274 former prison inmates released from 2000 to 2015 in North Carolina

\section{Key Findings}

1.87) than those without.

- Of the sample, 1329 died from opioid OD after release. At 2weeks, 1-year, and complete follow-up after release, the respective $\mathrm{OD}$ risk among former inmates was 40 (95\% $\mathrm{Cl}=30,51), 11(95 \%$ $\mathrm{Cl}=9.5,12)$, and 8.3 $(95 \% \mathrm{Cl}=7.8,8.7)$ times as high as general NC residents; the corresponding heroin overdose death risk among former inmates was 74 (95\% $\mathrm{Cl}=43,106), 18(95 \%$ $\mathrm{Cl}=15,21)$, and 14 $(95 \% \mathrm{Cl}=13,16)$ times as high as general NC residents, respectively.

- Former inmates at greatest opioid OD risk were those within the first 2 weeks after release, aged 26 to 50 years, male, White, with more than 2 previous prison terms, and who received inprison mental health and SUD treatment.

- Factors associated with increased risk of external cause mortality of cases vs. controls included use of heroin and other opioids in the community $(\mathrm{OR}=$ 2.20, 95\% Cl: $1.41-3.43$, $p<0.001)$, a prescription for antidepressants during . the current prison sentence $(\mathrm{OR}=1.94$, 95\% Cl: 1.02-3.67, $p=$ 0.042 ), a history of alcohol use in the community $(\mathrm{OR}=$ 1.54, 95\% Cl: $1.05-2.26$, $p=0.028$ ), and having ever served two or more custodial sentences $(\mathrm{OR}=1.51$, 95\% Cl: $1.01-2.25, p=$ 0.045).

- Being married $(\mathrm{OR}=$ 0.45, 95\% Cl: 0.29-0.70, $p<0.001)$ was protective.
Study Implications

- Former inmates are highly vulnerable to opioid overdose fatality and need urgent prevention measures.
- The study identified several behavioral, psychosocial, and clinical markers associated with mortality from preventable causes (i.e., drug overdose, suicide, accidents, violence) in people released from prison.

- Interventions that could be targeted at those at increased risk of external cause mortality include SUD treatment and harm reduction programs, improving transitional support programs and continuity of care for mental health, diversion and drug reform for repeat incarceration, and nurturing stable relationships during incarceration. - The period of 
Table 1 Summary of Articles Included in Scoping Review of Opioid Overdose Prevention for Justice-Involved Populations (Continued)

\begin{tabular}{|c|c|c|c|c|c|}
\hline Study & Study Objectives & Study Design & Sample/Setting & Key Findings & Study Implications \\
\hline & & & & $\begin{array}{l}\text { - Fewer predictors were } \\
\text { associated with cause- } \\
\text { specific mortality. }\end{array}$ & $\begin{array}{l}\text { imprisonment and } \\
\text { shortly after release } \\
\text { provides a unique } \\
\text { opportunity to } \\
\text { improve the long-term } \\
\text { health of ex-prisoners. }\end{array}$ \\
\hline $\begin{array}{l}\text { Wagner, Liu, } \\
\text { Davidson, } \\
\text { Cuevas-Mota, } \\
\text { Armenta, \& } \\
\text { Garfein, } 2015 \\
\text { [55] }\end{array}$ & $\begin{array}{l}\text { To identify venues } \\
\text { where high-risk PWID } \\
\text { could be targeted by } \\
\text { OEND interventions. }\end{array}$ & $\begin{array}{l}\text { Secondary analyses of } \\
\text { baseline data from a } \\
\text { cohort study }\end{array}$ & $\begin{array}{l}573 \text { PWIDs sampled } \\
\text { from community sites } \\
\text { in San Diego, CA }\end{array}$ & $\begin{array}{l}\text { - } 41.5 \% \text { reported past } \\
\text { heroin/ opioid } \\
\text { overdose, and } 7.9 \% \\
\text { had at least one } \\
\text { heroin/opioid overdose } \\
\text { in the past } 6 \text { months } \\
\text { - A higher proportion of } \\
\text { participants with past } \\
6 \text {-month overdose had } \\
\text { been arrested for any } \\
\text { reason ( } 43.2 \% \text { vs. } \\
25.7 \%), \text { had been } \\
\text { arrested for drug } \\
\text { possession ( } 27.3 \% \text { vs. } \\
7.3 \%), \text { and had their } \\
\text { syringes confiscated by } \\
\text { police (16.3\% vs. } 8.5 \%) \\
\text { - Individuals who had } \\
\text { been arrested for drug } \\
\text { possession in the past } \\
6 \text { months had } 4 \text { times } \\
\text { the odds of reporting } \\
\text { a recent heroin/opioid } \\
\text { overdose. }\end{array}$ & $\begin{array}{l}\text { - Identifying venues } \\
\text { outside of those that } \\
\text { traditionally target } \\
\text { services to PWIDs (i.e., } \\
\text { syringe exchange } \\
\text { programs) is critical to } \\
\text { implementing OEND } \\
\text { interventions at a scale } \\
\text { sufficient to address } \\
\text { the growing epidemic } \\
\text { of heroin/opioid- } \\
\text { related deaths }\end{array}$ \\
\hline $\begin{array}{l}\text { Winter, Stoové, } \\
\text { Degenhardt, } \\
\text { Hellard, } \\
\text { Spelman, } \\
\text { Jenkinson, } \\
\text { McCarthy, \& } \\
\text { Kinner, } 2015 \text { [56] }\end{array}$ & $\begin{array}{l}\text { This study aimed: (1) to } \\
\text { estimate the incidence } \\
\text { of self-reported NFOD } \\
\text { at three discrete time } \\
\text { periods following } \\
\text { release from prison, } \\
\text { among all released } \\
\text { prisoners and among } \\
\text { PWID, and (2) to } \\
\text { identify the pre-release } \\
\text { predictors of non-fatal } \\
\text { overdose among PWID }\end{array}$ & $\begin{array}{l}\text { Longitudinal cohort } \\
\text { study with structured } \\
\text { interviews at } 1,3,6 \\
\text { months post-release } \\
\text { from prison }\end{array}$ & $\begin{array}{l}1051 \text { prisoners from } \\
\text { selected prisons from } \\
\text { August, } 2008 \text { to July, } \\
2010 \text { who: (1) expected } \\
\text { release within } 6 \text { weeks, } \\
\text { (2) were sentenced, and } \\
\text { (3) imprisoned for at } \\
\text { least } 4 \text { weeks. } \\
\text { Participants were } \\
\text { generally representative } \\
\text { of all persons released } \\
\text { from prison in } \\
\text { Queensland, Australia } \\
\text { during the recruitment } \\
\text { period; women were } \\
\text { oversampled }\end{array}$ & $\begin{array}{l}\text { - The incidence of } \\
\text { reported overdose } \\
\text { was highest between } \\
1 \text { and } 3 \text { months post- } \\
\text { release: } 37.8 \text { per } 100 \\
\text { person-years (PY) } \\
\text { among PWID; } 24.5 / 100 \\
\text { PY among all ex- } \\
\text { prisoners. } \\
\text { - In adjusted analyses, } \\
\text { the risk of post-release } \\
\text { NFOD was higher for } \\
\text { PWID who reported: } \\
\text { o being unemployed for } \\
\text { > } 6 \text { months before } \\
\text { prison } \\
\text { o having been removed } \\
\text { from family as a child } \\
\text { ousing benzodiazepines } \\
\text { and/or pharmaceutical } \\
\text { opiates at least weekly } \\
\text { in the } 3 \text { months prior } \\
\text { to prison } \\
{ }^{\circ} \text { ever receiving OST } \\
{ }^{\circ} \text { having pre-release } \\
\text { psychological distress or } \\
\text { a lifetime mental disorder } \\
\text { - Risky alcohol use in } \\
\text { the year before prison } \\
\text { was protective. }\end{array}$ & $\begin{array}{l}\text { - Imprisonment is an } \\
\text { opportunity to initiate } \\
\text { targeted preventive } \\
\text { interventions such as } \\
\text { OST, overdose } \\
\text { prevention training } \\
\text { and peer-delivered } \\
\text { naloxone for those } \\
\text { with a high risk of } \\
\text { overdose. }\end{array}$ \\
\hline
\end{tabular}

$A O R$ adjusted odds ratio, $C I$ confidence interval, CJS criminal justice system, $D R D$ drug-related death, $E D$ emergency department, EMS emergency medical services, $H R$ hazard ratio, IDU injection drug use, IR incidence rate, MAT medication-assisted treatment, MOUD medication for opioid use disorder, N-ALIVE NALoxone InVEstigation Study, NESI Needle Exchange Surveillance Initiative, NFOD non-fatal overdose, NNP National Naloxone Program, OAT opiate agonist treatment, OD overdose, OEND overdose education and naloxone distribution, OR odds ratio, ORD opioid-related deaths, OST opioid substitution treatment, OUD opioid use disorder, PWID people who inject drugs, RCT randomized controlled trial, SMR standardized mortality ratio, SUD substance use disorder, THN take-home naloxone 
Two studies assessed the effects of training in naloxone use on willingness to intervene in an overdose. Bennett and Holloway [14] examined the impact of naloxone training on knowledge of overdose symptoms and confidence and willingness to respond among individuals sampled from community sites and prisons in Wales. Knowledge regarding overdose recognition and response increased among participants after the training, as well as participants' perceived confidence and willingness to administer naloxone. Moreover, over the course of the study, there were 28 reported uses of naloxone, resulting in 27 recoveries and one fatality. Another study sampled 31 men with an OUD history who were within 6 months of release from prison in Norway [21]. Nearly all participants reported they had previously witnessed an overdose, and about half had personally overdosed, ranging from one to 10 times. Participants scored high on a baseline knowledge assessment of risk factors, symptoms, and responses to opioid overdose, and their scores significantly increased following a brief naloxone training session on how to recognize and respond to opioid overdose with naloxone.

Contextual factors influencing an individual's ability and willingness to intervene in an overdose were the focus of two studies. Holloway, Hills, and May [19] interviewed 55 participants in Wales (82\% male); $78 \%$ had ever been incarcerated and about half (47\%) were currently incarcerated. Most had undergone training in naloxone use (78\%) and $80 \%$ had a personal overdose history. They identified barriers related to micro factors, e.g., norms within the setting, such as problems identifying an overdose, panic and confusion as well as the individual's own intoxication and limited ability to effectively intervene; and macro factors, such as fear of criminal justice repercussions should they be found in possession of drugs at the scene. Participants often did not carry the naloxone kit with them or have it available at the time they were in an overdose situation; they viewed the kit as burdensome, but also as potentially attracting police attention. Moreover, some participants held negative views of naloxone, given that it may precipitate severe withdrawal symptoms. The authors advocated for expanding harm reduction interventions, including supervised injection facilities and decriminalization of heroin to create a less punitive context for overdose prevention.

Similarly, Koester and colleagues [20] applied a structural risk environment framework to analyze qualitative interviews with injection drug users from two community-based studies, including individuals using syringe exchange programs in Denver. Despite the passage of a Good Samaritan law in Colorado that provided limited immunity to both the witness and victim in a drug overdose where illicit drugs were present, few participants had called Emergency Medical Services (EMS) in an overdose situation. Participants cited aggressive local policies regarding homelessness and police enforcement of misdemeanors that led them to fear that calling EMS could jeopardize their legal status or that of the overdose victim. They were particularly afraid that police contact would lead to an identify search, potentially exposing outstanding warrants or parole/probation violations, resulting in their arrest or incarceration, as well as possibly losing their public housing. The authors suggested decisions about whether to call 911 are calculated within the broader community context, and that structural changes to policing practices and decriminalization of drug use would facilitate harm reduction interventions.

\section{Accessibility}

Four studies addressed the relationship of criminal justice system involvement with naloxone access. These studies sampled individuals outside of correctional settings, including three community epidemiological surveillance projects. Collectively, these studies show the interface between prison and community-based naloxone distribution programs.

Barocas et al. [22] examined overdose history and naloxone training among a sample of injecting drug users from a syringe exchange program in Wisconsin. Forty percent of the sample had a history of incarceration and these individuals were more likely to have observed an overdose in the past and received prior naloxone training; however, none had received naloxone training while incarcerated, but rather had been trained through a syringe exchange program.

Three community-based epidemiological surveillance studies examined the relationship of incarceration history with access to naloxone. In Scotland's national Needle Exchange Surveillance Initiative (NESI), a representative sample of people who inject drugs (mainly heroin) was assessed every 2 years. In a time series analysis, McAuley et al. [24] examined access to naloxone over two time periods: 2011-2012 and 2013-2014. Although the proportion who reported they were carrying naloxone at the time of the survey decreased over time (16 to $5 \%$ ), the proportion who stated their last naloxone supply was obtained from prison was relatively stable (16 and 19\%). The authors interpreted the decision to carry naloxone as based in part on its perceived availability within the community, which had increased over time, as well as the individuals' perceived level of personal risk. In addition, the authors surmised that individuals who had been incarcerated may be reluctant to carry a naloxone kit obtained from prison because its bulky size and distinctive yellow color make it conspicuous and highlight their status as an injection drug user. 
A second study using data from the NESI further examined the source of naloxone among individuals in the community [23]. The proportion of individuals in the NESI who had obtained naloxone in the past year increased from 2011 to 12 to 2013-14, from about 13 to 51\%; however, there was a decrease in the proportion who had obtained naloxone from prison between 2013 and 14 and 2015-16. The authors surmise this decrease reflected the increasing availability of naloxone within the community. Moreover, they found receipt of naloxone among individuals released from prison in the past year was higher among women than men ( $67 \%$ vs. $39 \%$, respectively) and among individuals aged 35 and younger compared to older individuals (48\% vs. $37 \%$, respectively).

A surveillance study conducted in the United Kingdom assessed overdose history and naloxone access in annual cross-sectional surveys with injection drug users recruited from syringe exchange programs and drug treatment programs [25]. In 2013-2014, 91\% of the sample reported injecting heroin and 15\% reported having overdosed in the prior year. Less than half $(45 \%)$ of those with a past-year overdose reported they had received naloxone, whereas the reminder were unsure. Among individuals with a past-year overdose, those who had ever been incarcerated had higher odds of receiving naloxone (odds ratio $[\mathrm{OR}]=1.59$ ) relative to those without incarceration history; however, injecting two or more drug and having received used injection equipment were associated with lower odds of naloxone receipt, which suggests high-risk among this group.

\section{Effectiveness}

Seven studies addressed effectiveness of overdose prevention programs for justice-involved populations using a variety of interventions and study designs. The most comprehensive evaluation examined Scotland's National Naloxone Program (NNP), which was a large-scale national program to provide brief training and naloxone kits to individuals at risk of opioid overdose. From 2011 to 13 , the NNP issued nearly 12,000 naloxone kits to individuals at release from prison and within the community. The primary outcome analyses compared opioid-related deaths (ORDs) within 4 weeks of prison release using national mortality records and prison service records extracted from two time periods: 20062010 (before) and 2011-2013 (after) implementation of the NNP. ORDs decreased from 9.8 to $6.3 \%$ in $2011-13$, a difference of $3.5 \%$, which they estimated to be a reduction in 42 prison-release ORDs [27].

In a subsequent time series analysis, Bird \& McAuley [26] evaluated changes in ORDs from 2011 to 2016 in Scotland. The NNP supplied almost 36,000 naloxone kits during this time to people at risk in the community and at prison and hospital discharge. They determined there was a $50 \%$ reduction in ORDs (from 10 to 5\%) within 4 weeks of prison release (primary outcome). This national program model has been adapted and implemented in England, Wales, Norway, and British Columbia, Canada; however, progress is slower in Australia and the U.S. In addition, the investigators note the complexities of evaluating outcomes based on non-experimental, timeseries data, given the number of ORDs in Scotland increased since the NNP was introduced, particularly among individuals who were 35 years or older, confounding the ability to determine effects of the program through before and after comparisons.

Three studies evaluated naloxone training programs in criminal justice settings. Huxley-Reicher et al. [29] evaluated outcomes of a training session on overdose rescue for visitors to Rikers Island Jail in New York City. Individuals who completed the training and returned to request a naloxone kit were recruited into the study. Of those who completed a 6-month follow-up, $14 \%$ had witnessed one or more overdoses, for a total of 70 overdose events; $17 \%$ of these were among individuals who had been recently released from prison or jail. Ten percent of the participants administered naloxone at least once over the study period; $87 \%$ of the recipients survived the overdose. The authors concluded that the correctionsbased visitor training program was effective in reaching individuals who were likely to be present at an overdose and equipping them to respond.

A second intervention study evaluated a naloxone training program that used a simulation test to evaluate participants' ability to apply the techniques. Participants were 85 individuals within 4 weeks of their release from the Rhode Island correctional system [30]. Prior to incarceration, about one third (35.5\%) had personally experienced an overdose and $70 \%$ had witnessed an overdose. Over half $(52 \%)$ correctly administered intranasal naloxone, and 19\% were sub-optimal in their administration. The authors concluded that simulation training allows individuals to learn and practice the intervention within the confines of a correctional environment prior to their release.

A third intervention study conducted follow-up surveys over 4 years with 637 participants who were trained in naloxone use while incarcerated in jail in San Francisco [32]. Two thirds of participants received naloxone upon release; of these, approximately $32 \%$ reported reversing an overdose and 44\% received naloxone refills after their release. Nearly all (96\%) received the refills at a syringe exchange program or other community-based program, and only $4 \%$ received naloxone in a subsequent incarceration. Participants requested refills because the original supply had been lost, used to reverse an overdose, stolen, or given to someone else. 
Distribution of naloxone to others played a prominent role in terminating the experimental study to assess the effectiveness of the N-ALIVE program in England, which provided naloxone to 1685 individuals who were within 3 months of their scheduled release from prison [31]. The study was implemented at 16 prisons and $72 \%$ of eligible prisoners consented to randomization. Among those who completed a follow-up assessment, $67 \%$ had used heroin within 2 weeks of release, $5 \%$ had personally overdosed, and $15 \%$ had witnessed another's overdose. Yet only one-third of the reported naloxone administrations were to the study participants as there was a high rate of diversion, i.e., study participants had used it on others who had overdosed, rather than having it available for others to administer to them in an overdose. The investigators terminated the trial because they determined that the individual-level randomization was compromised and naloxone kits were distributed to individuals in the control condition [57]. There were 9 overdose deaths within 12 weeks following community re-entry, but the investigators argue that conclusions about effectiveness of THN could not be inferred due to the early cessation of the trial.

Lastly, Green, Ray, Bowman, McKenzie, \& Rich [28] reported 2 cases studies of participants in an overdose prevention program (described in Green et al. [33]) who successfully self-administered intranasal naloxone following release from prison in Rhode Island. Both individuals had used heroin for at least 10 years prior to their incarceration, had been incarcerated for 3-4 months, and did not use while incarcerated. One male overdosed on the first day after his release and one female, overdosed 17 days after release upon her first heroin injection. Both were assisted by friends in the situation, instructed them how to assemble the naloxone kit, and successfully self-administered one dose. The authors concluded that these examples provide evidence of the effectiveness of the training program on how to recognize signs of overdose, assemble and administer naloxone, and the importance of teaching others these techniques and enlisting their aid in an overdose situation.

\section{Feasibility}

Five studies examined the process of developing and/or implementing overdose prevention programs within criminal justice settings using primarily descriptive methods.

Pearce et al. [33] conducted focus groups and interviews to evaluate the implementation of a take-home naloxone (THN) program in two pilot correctional facilities in British Columbia, Canada. Challenges to scheduling the trainings within prison stemmed from logistical issues related to staff coverage, timing of programs, and extra resources needed to cover additional staff. In addition, linking individuals to harm reduction programs after release, to ensure continuity of prevention strategies, was problematic. Nevertheless, the authors concluded that successful implementation of overdose prevention programs in prisons can occur by adapting resources to meet the needs of the incarcerated population and facility operations.

Similarly, Sondhi, Ryan, \& Day [35] evaluated the implementation of a THN program across 10 prisons in England using focus groups with participants and interviews with operational staff. They identified barriers related to confusion about the program among both staff and participants, difficulties identifying and engaging eligible participants, lack of integration of the program within prison processes, and the need for senior prison staff to support a "culture of change" for successful implementation. Moreover, there was a fundamental conflict in advocating for a harm reduction approach within the context of abstinence and recovery-based treatment programs within the prisons.

These same challenges were echoed by Horsburgh \& McAuley [36] in their description of the National Naloxone Programme within the Scottish Prison Service. The program was developed in conjunction with a community-based peer education training program, the Scottish Drugs Forum, and initially implemented in 4 prisons. They documented logistical challenges, including scheduling key personnel (i.e., trainers and participants) to be present at the same time/place, competing priorities for prisoners leading to high participation refusal rates, limited time availability of staff, and additional staff needed to escort prisoners to groups. From an individual perspective, individuals were reluctant to discuss emotionally charged issues in groups within prison, such as personal experiences of overdose or loss of others by overdose; having to practice basic life support may have been intimidating for some in a group setting. From the organizational perspective, prison officers lacked understanding about naloxone and often neglected to follow-through in placing naloxone kits with prisoner possessions for collection at discharge.

On a smaller scale, Zucker et al. [34] described the implementation of a pilot overdose prevention program at a minimum security facility in New York that provided training and naloxone kits to prisoners prior to their release. Key to its successful implementation, and expansion to other facilities, was leadership from the state Department of Corrections and their coordination with the prisons and community-based organizations that provided training and naloxone kits to family members and friends of the incarcerated individual.

Lastly, Green et al. [37] described a two-stage process of developing and implementing an overdose prevention 
video targeted to prisoners. First, a formative component consisted of a systematic review of 9 educational videos on opioid overdose prevention, recognition, and/or intervention. Input and feedback were obtained from formerly incarcerated injection drug users recruited from syringe exchange programs in Providence, Rhode Island; national experts on overdose prevention; and overdose prevention staff. Second, using input from stage one and following the social learning model, they created a 19-min film, Staying Alive on the Outside, that depicts interviews, conversation and model training sessions by peers. Content includes the challenges of reentry from prison, OUD and relapse, and misconceptions about opioid tolerance and overdose. Viewers learn strategies to avoid opioid overdose and what to do in an overdose situation. Peer 'learners' and peer 'trainers' model the dissemination of education and naloxone administration. The resulting theory-based video containing prison-specific overdose information and informed by input from end-users was disseminated to other correctional facilities for re-entry planning.

\section{Participant overdose risk \\ Temporal patterns in overdose risk following release}

Five studies provided evidence that the maximal period of overdose risk is within the initial 2 weeks to 1 month following release from prison or jail. These studies employ similar methodologies, which include merging data from prisoner records with death registries to track mortality outcomes following release.

In order to evaluate the effects of a national policy that enacted prison-based medication-assisted treatment (MAT), Bird, Fischbacher, Graham, and Fraser [43] compared drug-related deaths (DRD) in the 12 weeks following prison release before and after the policy change. Data from Scotland's prisoner database was linked with death registrations to compare the periods before (1996-2002) and after (2003-2007) the program's implementation (note: data on opioid-specific deaths were not available prior to 2000, hence use of DRD as the primary outcome). Before program implementation there were 3.8 DRDs per 1000 releases; of these, $57 \%$ occurred in the first 14 days. After introduction of the program in 2002, the rate of DRDs was significantly reduced to 2.2 per 1000 releases over 12 weeks; there was a higher percentage of DRDs among younger compared to older prisoners. There was no change, however, in the proportion of DRDs or for opioid-related deaths (for 2000-07) that occurred in the first 14 days after release, suggesting that in-prison MAT did not have a significant effect in the initial period.

Similarly, Bukten et al. [44] analyzed records from the Norwegian Prison Registry and Norwegian Cause of
Death Registry for over 90,000 individuals released from prison over a 15-year period (2000-2014). Overdose deaths accounted for $85 \%$ of all deaths during the first week following release, with a peak in the 2 days following release. Compared with week 1 , the risk of overdose death was reduced by more than half during week 2 and to one-fifth in weeks 3-4. In addition, the risk was greatest for those serving 3-12 months compared with shorter or longer periods.

In another retrospective cohort study, Pizzicato et al. [52] merged incarceration data with overdose fatality and death records for 82,780 incarcerated individuals released from the criminal justice system in Philadelphia from 2010 to 2016. Individuals released from incarceration, compared with matched cases in the general population, had higher risk of overdose death (standardized mortality ratio [SMR]: 5.29), with the greatest risk during the first 2 weeks following release (SMR: 36.91). There was a lower risk of overdose death for Blacks (Hazard Ratio [HR]: 0.17) and Hispanics (HR: 0.41) than white, non-Hispanics. Individuals who had a serious mental illness were at higher risk of overdose (HR: 1.54) than those without.

In a definitive study, Ranapurwala et al. [53] examined the risk of opioid overdose death among approximately 229,000 individuals released from prison from 2000 to 2015 in North Carolina, relative to the general population. In the first year after release, former inmates had over 10 times the risk of opioid-related overdose fatality $(\mathrm{SMR}=10.6)$ relative to the general population. As in prior studies, the risk was highest in the first 2 weeks after release $(S M R=40.5)$. In multivariable analyses, the risk of overdose was higher for individuals who were aged 26 to 50, male, and/or White; had more than 2 prior incarcerations; and had received in-prison mental health and SUD treatment.

In a study of detainees released from jail, Alex et al. [38] examined the rate of death within 6 weeks following release from New York City jails in 2011-2012. Opioid overdose accounted for the highest share of deaths among the 59 decedents (37\%), which exceeded deaths due to other drug overdose, chronic disease, and assaultive or other forms of trauma. Moreover, $77 \%$ of those who died from opioid overdose had a history of prior overdose or opioid detoxification, $14 \%$ were released with a methadone dose, and half (50\%) were referred to opioid treatment within the community at release. Thus, the low rates of in-jail methadone dosing as well as referral to methadone treatment in the community were insufficient protection from opioid overdose. The findings support the need for greater efforts to link individuals to treatment and to distribute naloxone at release. 


\section{Service system interactions following release}

Five retrospective cohort studies examined contact with service providers/settings among people who overdosed following their release from prison or jail or who had prior criminal justice involvement. These studies identified service systems that are frequently utilized by justice-involved individuals and provide opportunities for overdose prevention interventions.

Service system interactions were identified in a study by Andersson et al. [39] that used records data on 180 opioid-related deaths in Sweden. Most (89\%) of the deceased individuals had been in contact with one or more agencies in the year prior to death; $75 \%$ with health care services, $69 \%$ with social services, $28 \%$ with prison and probation, and $23 \%$ who had been enrolled in methadone treatment. Moreover, sedatives were present in more than $80 \%$ of the cases and individuals whose deaths were buprenorphine-related had been in contact with social services to a significantly lesser extent during the year prior to death.

Binswanger, Nguyen, Morenoff, $\mathrm{Xu}$, and Harding [42] used records data to examine risk of death in relation to community corrections supervision among 140,266 individuals in Michigan from 2003 to 2006. Over approximately $7-8$ years, $15 \%$ of the 1131 deaths were due to overdose (102.8 per 100,000 person-years). Of these, $58 \%$ had occurred in the community, $29 \%$ on probation, and $13 \%$ on parole. The adjusted risk of overdose death was lower on probation $(\mathrm{HR}=0.71)$ than in the community without probation or parole $(\mathrm{HR}=1.00)$, but not significantly different on parole $(H R=1.13)$. Presentence daily opioid use $(H R=3.54)$ was associated with increased risk of opioid overdose, whereas drug possession and delivery convictions were not. The authors concluded that overdose prevention interventions be incorporated in parole, probation, and community settings that are frequented by individuals following release.

Similarly, Hacker et al. [47] examined service system contacts preceding opioid overdose fatality among 1399 individuals in Alleghany, PA from 2008 to 2014. A majority of the sample (68\%) had a public human service encounter before overdose death; of these, $55.5 \%$ had been incarcerated in the county jail, $64 \%$ had used a mental health service, and 73\% had used SUD services. Among those with past-year incarceration prior to their overdose death, $26 \%$ overdosed within 30 days of their last release from jail. Moreover, contact with service agencies often occurred in the immediate period preceding overdose. Among those who had used mental health services, $45 \%$ overdosed within 30 days of their last service contact, as did $38 \%$ of those who had used SUD services in the past year. Given the high rates of overdose death among individuals who have recent contact with mental health or SUD services, the authors recommended the use of screening and brief interventions to identify individuals at risk.

In a population-based data-linkage study, Larochelle et al. [50] analyzed data from the Massachusetts Public Data Warehouse to identify potential "touchpoints" for intervention with individuals at risk of overdose. The study identified individuals in the general population (i.e., 6.7 $\mathrm{M}$ residents aged 11 years or older with information on sex and age who were identified in the All-Payer Claims Database) who had died from opioid overdose from 2011 to 2015. Critical encounter touchpoints included contacts with the public health, criminal justice, or health care systems. The highest risks of fatal opioid overdose, relative to the general population, were for individuals who had contacts related to: prior nonfatal opioid overdose $(\mathrm{SMR}=111)$; opioid detoxification $(\mathrm{SMR}=66.1)$; injection-related infection $(\mathrm{SMR}=54.1)$; release from prison or jail $(\mathrm{SMR}=30.0)$; and for any of 8 critical encounter touchpoints $(\mathrm{SMR}=68.4)$. Over half (52\%) of the deceased individuals had interacted with any of the touchpoints in the 12 months preceding death. The authors concluded that these system touchpoints can be used to intervene with individuals at high opioid-overdose risk.

Likewise, Wagner et al. [55] identified promising venues for overdose prevention using baseline data from a cohort study of 573 people who inject drugs in San Diego, CA. Over two-fifths of the sample (41.5\%) reported past heroin/opioid overdose and $8 \%$ had at least one heroin/opioid overdose in the past 6 months. A higher proportion of individuals who overdosed in the past 6 months had also been arrested for any reason ( $43 \%$ vs. $26 \%$ ) or for drug possession ( $27 \%$ vs. $7 \%$ ), and had their syringes confiscated by police (16\% vs. $9 \%)$, compared to those without overdose. Individuals who had been arrested for drug possession had 4 times the odds of a recent heroin/opioid overdose. The authors concluded that it is critical to implement overdose prevention interventions in health care and criminal justice systems, in addition to those that traditionally target people who inject drugs (i.e., syringe exchange programs).

\section{Environmental and behavioral risk factors for overdose following release}

Nine studies assessed environmental and behavioral risk factors associated with opioid-related relapse, non-fatal overdose, and mortality following release from prison. In a qualitative study, Binswanger et al. [40] surveyed 29 prison inmates within 2 months following their release on their drug use experiences, perceptions of overdose risk, and overdose experiences. Participants were recruited from a community health center, an urgent care 
center, and addiction treatment centers, as well as by snowball sampling, in Denver, Colorado. The following themes were identified: 1) Relapse to drugs and alcohol occurred in a context of poor social support, medical comorbidity, and inadequate economic resources; 2) Former inmates experienced pervasive exposure to drugs in their living environments that posed a risk of relapse; 3) Intentional overdose was considered "a way out" of situational stressors and accidental overdose was perceived as related to decreased tolerance; and 4) Protective factors included structured drug treatment programs, spirituality/religion, family, and community-based resources, such as self-help groups. They concluded that overdose prevention interventions for this population should include structured treatment with gradual transition to the community, enhanced protective factors, and reductions of environmental triggers to use drugs.

In a nested case-control study using data from the Washington State Department of Corrections, Binswanger et al. [41] identified risk and protective factors for all-cause and overdose death following release from prison. Clinical data on SUD and mental health disorders were extracted from prison medical charts. The study included cases (699 all-cause deaths and 196 overdose deaths) between 1999 and 2009 that were matched 1:1 to controls on sex, age, and year of release. Key risk factors for overdose-related mortality derived from multivariate models included having a positive screen for substance dependence, history of injection drug use, history of panic disorder, receipt of a psychiatric prescription in the 60 days before release, and opiates/sedatives as the drug causing the most serious problem. Conversely, being of Hispanic ethnicity and other race/ ethnicity (vs. non-Hispanic whites) and having a child were associated with a reduced risk of overdose death. SUD treatment during the index incarceration was protective for both all-cause $(\mathrm{OR}=0.67)$ and overdose $(\mathrm{OR}=0.57)$ mortality, although the MOUD was not available within the state prison system at the time of the study. The authors suggest that prisons should proactively identify individuals at high risk of death following their release through their administrative and clinical data systems, and target those individuals for prevention interventions.

In order to understand the context of the post-release risk environment, Cepeda et al. [45] conducted semistructured in-depth interviews with formerly incarcerated individuals who had a history of injection drug use. Participants were recruited from street outreach $(n=20)$ and a drug treatment center $(n=5)$ in St. Petersburg, Russia. Factors related to overdose included financial instability due to unemployment, negative interactions with police, return to a drug-using community, and reuniting with drug-using peers. Almost half the sample overdosed on opioids after release, with a median time of 30 days after release. Individuals who relapsed immediately after release seemed resigned to the inevitability of relapse, whereas others who wanted a new start were more motivated and sustained several months before relapsing. Alcohol or stimulant use often preceded opioid relapse, and alcohol use often preceded opioid overdose. The participants seemed unaware that they were at heightened risk of overdose following a long period of abstinence while incarcerated. The authors concluded that post-release interventions are needed to link people who inject drugs to social, medical, employment, and harm reduction services, and that pre-release overdose prevention should address the heightened risk of overdose due to loss of tolerance as well as risks from alcohol use.

In a prospective cohort study, Forsyth, Carroll, Lennox, and Kinner [46] estimated the incidence of death and identified risk factors for mortality among adults released from prisons in Queensland, Australia. Baseline survey data from 1320 adults recruited in prisons within 6 weeks of expected release, between 2008 and 2010, were linked with data from a national death register covering a period up to 4.7 years in the community. The cohort's mortality rate was higher than in the age- and sex-matched general population for all causes $(\mathrm{SMR}=$ $4.0)$ and drug-related causes $(\mathrm{SMR}=32)$. In a multivariable model, adjusting for age, sex, and indigenous status, factors associated with increased mortality risk included expecting to have average or better funds available on release $(\mathrm{AHR}=2.9)$, poor mental health $(\mathrm{AHR}=2.6)$, and lifetime history of overdose $(\mathrm{AHR}=2.5)$. Overall, people at greatest risk of death from drug-related causes are characterized by poor physical and mental health and risky substance use, including lifetime history of overdose.

In secondary analysis of data from a retrospective cohort study, Spittal et al. [54] identified modifiable risk and protective factors for external cause and causespecific mortality after release from prison. The study used medical records data for 572 inmates released from prison from 1994 to 2007 (286 treatment and 286 matched controls) in Queensland, Australia. Increased risk of external-cause mortality (i.e., drug overdose, suicide, transportation accidents, and violence) was associated with using heroin and other opioids in the community $(\mathrm{OR}=2.20)$, being prescribed antidepressants during the current incarceration $(\mathrm{OR}=1.94)$, using alcohol in the community $(\mathrm{OR}=1.54)$, and having served two or more custodial sentences $(\mathrm{OR}=1.51)$. Being married $(\mathrm{OR}=0.45)$ was protective. A greater number of prior incarcerations and having used heroin/other opioids in the community were specifically associated with drug overdose mortality, controlling for other factors. The authors concluded that interventions to reduce the 
risk of external cause mortality include SUD treatment and harm reduction programs; transitional support programs, and continuity of care for mental health treatment; diversion and drug reform to reduce repeat incarceration; and support for building stable relationships during incarceration.

Four studies focused on predictors of non-fatal overdose among individuals released from prison. Keen et al. [48] used medical records data from ambulances, hospitals, and EDs for 1307 participants in a prior prisonbased study in Queensland, Australia. Approximately 8\% of participants had at least one non-fatal overdose that required medical care during a median follow-up period of 2.9 years. The crude incidence rate (IR) of non-fatal overdose was 47.6 per 1000 person-years. The rate was highest in the first 14 days after release from prison (IR = 296 per 1000 person-years), which is 3.6 times higher than in the following 10 weeks. Moreover, $41 \%$ of opioid-related overdoses that resulted in hospital admission were attributed to intentional self-harm in medical records. In multivariate analyses, non-fatal overdose after release from prison was positively associated with a recent history of SUD, comorbid mental illness and SUD, lifetime injecting drug use, lifetime non-fatal overdose, being dispensed benzodiazepines after release, a shorter index incarceration, and low perceived social support. However, one-third of those who experienced a non-fatal overdose after release had no prior overdose, and overdose was not limited solely to injection drug users. Surprisingly, the risk of overdose was lower for people with high-risk alcohol use. The authors acknowledged imprecision in drug specificity related to overdose in medical records. They concluded that overdose prevention requires coordinated transitional care between prison and the community, particularly in the immediate period following release when risk is increased due to loss of drug tolerance.

In another study focusing on non-fatal overdose, Kinner et al. [49] conducted a prospective cohort study of 2515 community-recruited illicit drug users followed from 1996 to 2010 in Vancouver, Canada to identify risk and protective factors in relation to recency of incarceration. One third of participants reported at least one recent non-fatal overdose, and the risk was higher among those recently incarcerated $(\mathrm{OR}=2.13)$. Risk factors independently and positively associated with non-fatal overdose included daily use of heroin, benzodiazepines, cocaine, or methamphetamine; binge drug use; public injecting; and previous overdose. Older age, methadone maintenance treatment, and HIV+ status were protective against overdose. The investigators concluded there is an urgent need to develop and implement evidencebased preventive interventions for ex-prisoners that target these modifiable risk factors.
In secondary analyses of cross-sectional surveys of 2288 adults in prison who were participating in separate studies in New South Wales (NSW) and Queensland, Australia, Moore et al. [51] estimated the prevalence and correlates of lifetime overdose. Across both cohorts, 23\% of participants reported a lifetime history of non-fatal overdose. Although the lifetime prevalence of non-fatal overdose differed across the two samples, the correlates were similar. A history of injecting heroin more than doubled the odds of non-fatal overdose across the NSW and Queensland samples (AORs $=2.07,2.43$, respectively). Similarly having ever injected other opioids increased the odds of overdose $(\mathrm{AORs}=2.81,1.78$, respectively). They concluded that understanding the risk factors for non-fatal overdose in this population is necessary to inform targeted, evidence-based riskreduction interventions.

In a longitudinal cohort study, Winter et al. [56] estimated the incidence of self-reported non-fatal overdose at three discrete time periods following prison release to identify the pre-release predictors of overdose among injecting drug users. Study participants were 1051 prisoners from selected prisons in Queensland, Australia from 2008 to 2010 who had been imprisoned for at least 4 weeks and were due to release within 6 weeks. Data were obtained through structured interviews at 1,3 , and 6 months post-release from prison. The incidence of reported overdose was highest between 1 and 3 months post-release (37.8 per 100 person-years among drug injectors; 24.5/100 person-years among all ex-prisoners). In adjusted analyses, the risk of post-release non-fatal overdose was higher for individuals who reported being unemployed for over 6 months before prison, having been removed from family as a child, using benzodiazepines and/or prescription opioids at least weekly in the 3 months prior to prison, ever receiving methadone treatment, and who reported pre-release psychological distress and a lifetime history of mental disorder. Conversely, risky alcohol use in the year before prison was protective. The authors argued preventive interventions initiated during incarceration, such as MAT, overdose prevention training, and peer-delivered naloxone, should target individuals at high risk of overdose.

\section{Discussion}

This study used a systematic search process to identify 43 papers published between 2010 and 2020 that reported findings relevant to opioid overdose prevention for justice-involved populations. A prior scoping review identified the programmatic features of post-overdose interventions [58]; in contrast, this review focused on the risk factors and overdose experiences of justiceinvolved individuals, the settings in which interventions for this population can be implemented, the 


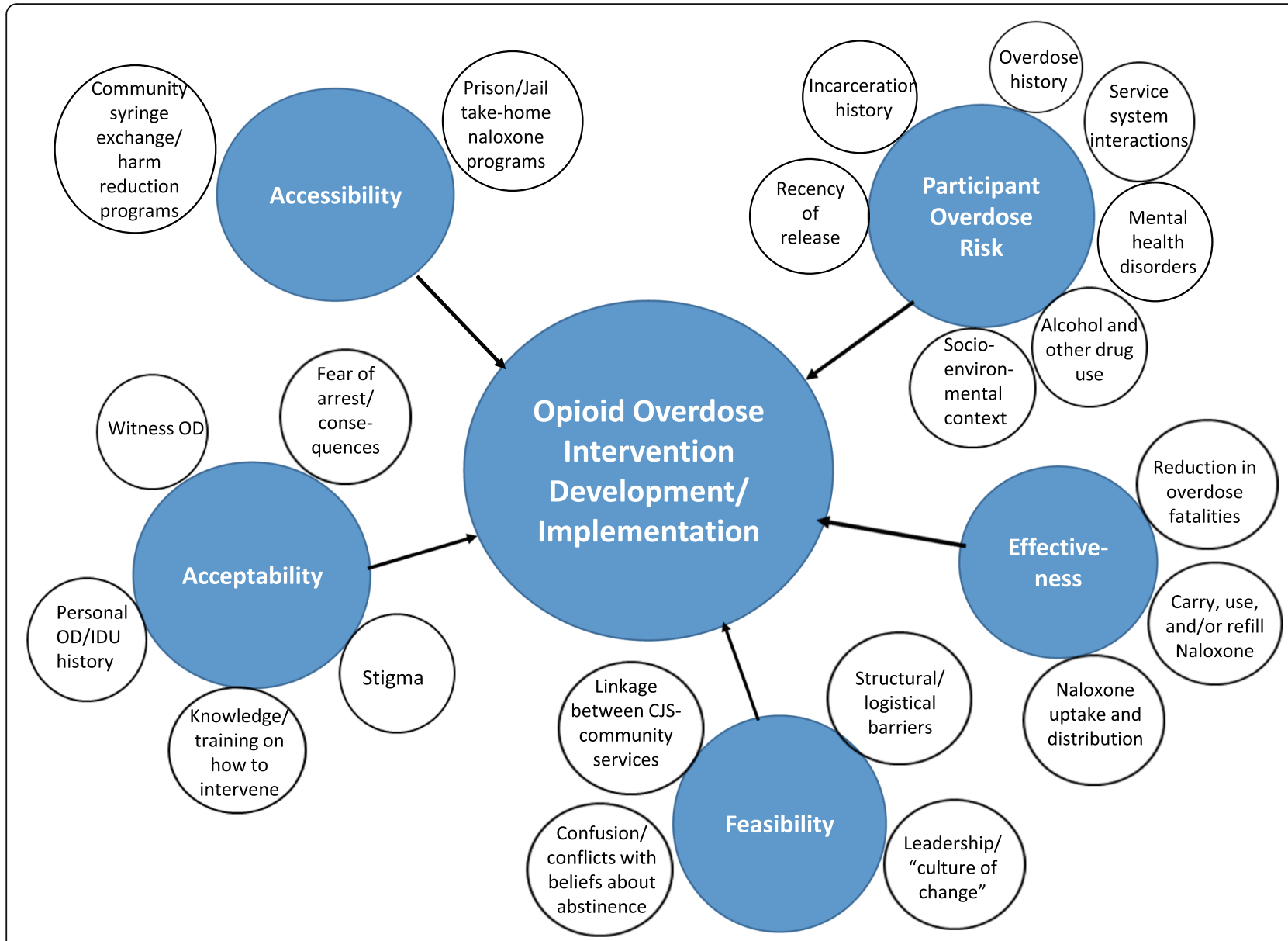

Fig. 2 Conceptual Map: Factors that Influence Opioid Overdose Prevention for Justice-Involved Populations

implementation barriers, and outcomes of overdose prevention interventions, i.e., training on use of naloxone and take-home naloxone programs. A qualitative analysis identified and assessed five thematic domains: acceptability, accessibility, effectiveness, feasibility, and participant risk of overdose. Common themes associated with each of these categories are graphically depicted in Fig. 2.

\section{Acceptability}

A robust finding across studies was the association of the personal history of heroin use, and especially having previously overdosed or witnessed another's overdose, with an individual's knowledge of naloxone and willingness to be trained in its administration. The community context can serve either as a barrier or facilitator of naloxone use, stemming from perceptions of naloxone availability within the community, stigma associated with carrying naloxone, and fear of police or criminal justice involvement from being in an overdose situation. While similar concerns regarding naloxone use and administration have been documented in studies of more general populations [59, 60], fears related to potential arrest are likely higher among justice-involved individuals. Input from formerly incarcerated individuals was critical to determining the factors that increased or inhibited their willingness to intervene in an overdose situation.

\section{Accessibility}

Community-based studies, included those with targeted sampling from community programs as well as systematic surveillance surveys, indicated that although some individuals had obtained naloxone through prison, access to naloxone was largely a function of the community supply, principally through syringe exchange programs or other community providers. Although naloxone provision at discharge is critical, the study findings demonstrated the importance of linking individuals to community-based providers for ongoing access. Further, these findings highlight the importance of the interface between correctional systems and community providers in facilitating successful re-entry, including 
linkage to SUD treatment and overdose prevention programs, and the need to strengthen these relationships.

\section{Effectiveness}

There was limited research on the effectiveness of overdose prevention approaches, particularly across settings. Most studies used one-group pre/post evaluations; more rigorous time-series analyses, such as the evaluation of Scotland's National Naloxone Program in Scotland, provided evidence of reductions in opioid-overdose deaths, at the same time suggesting the importance of synergy with community-based distribution programs. Evaluations of naloxone training and distribution programs at jails and visitor's programs, while showing evidence of uptake through reported use of naloxone and refills, can be expanded to better understand the factors associated with measurable outcomes, i.e., reductions in opioid overdose and related fatalities.

\section{Feasibility}

Challenges to implementing overdose prevention interventions included the logistical constraints within prison related to scheduling, staffing, and resources as well as lack of staff understanding about of how to integrate overdose prevention into the discharge process. Input from end-users was important to developing interventions that address the unique challenges and concerns of individuals re-entering the community from prison. The larger organizational context could facilitate implementation through leadership that fostered a "culture of change" as well as collaborations with community providers to provide training to correctional staff and to ensure linkage and continuity at release. A significant barrier to implementation, however, is the tension between a harm reduction approach that acknowledges the possibility of relapse to opioids following release and the adherence to abstinence-based recovery that pervades the criminal justice system [61, 62], including among parole and probation officers who monitor individuals following their release [63].

\section{Participant risks of overdose}

Understanding the overdose risk environment is necessary for developing and implementing effective overdose prevention interventions and policies [64-66]. Three domains associated with risk of overdose among justiceinvolved individuals were identified: temporal associations, service system interactions, and participant and environmental characteristics. Retrospective cohort studies demonstrate that the maximal risk of overdose is in the immediate period following discharge to the community, typically 2 weeks to 30 days. This finding suggests overdose prevention interventions are critically important in the immediate post-release period.
Secondly, individuals at risk of opioid overdose often interact with a range of community-based service providers following their release and preceding overdose, which provide opportunities for overdose prevention interventions. Third, several studies converged on a set of participant characteristics that are associated with overdose history or fatality; these include severity of drug use disorder, mental health problems, and lack of social support. Indicators of mental health severity were consistently associated with overdose risk. Risks within the post-release environment include access to drugs, return to drug-using social networks, and lack of social and socio-economic supports that exacerbate risks of relapse and overdose. An anomalous finding emerged regarding alcohol use; several studies found that risky alcohol use was associated with higher risk of opioid overdose, whereas two studies $[48,56]$ found protective effects of alcohol use.

\section{Study limitations}

Study limitations stem from the nature of scoping reviews, which aim to characterize the size and scope of research on a topic, but do not include a quality assessment of studies nor quantitative synthesis of common outcomes [67]. Thus, this review included studies that ranged across various study designs, populations, and settings, as appropriate to the research questions. Studies were included that were situated in either correctional or community settings, which have distinct features, yet an overarching finding was the importance of the interface between corrections and community overdose prevention efforts for justice-involved individuals.

\section{Conclusion}

Following the suggestions of Levac and colleagues [68] regarding strategies to improve the methodology of scoping reviews and their relevance to health care delivery, we address the implications of this study's findings for research and policy. Regarding research, although several studies identified barriers to implementing overdose prevention programs within prisons, research is lacking on the effectiveness of different strategies for implementing overdose prevention in correctional and community settings. More research is needed on the effectiveness of overdose prevention interventions and how to optimize their implementation across correctional and community settings. Generally, more rigorous research is needed on outcomes of overdose prevention programs, which thus far have been limited and generally small-scale (with the exception of Scotland's $\mathrm{Na}$ tional Naloxone Program).

The study findings demonstrated that collaborations across corrections and community providers is critical to overdose prevention. A growing body of research has 
examined strategies for building collaborations among these systems for continuity of MOUD provision following release from prison $[69,70]$. Policies promoting the training in naloxone use and its distribution can build upon this existing platform to incorporate overdose prevention, as well as to address differences related to professional orientation and beliefs about abstinence and medication use. Moreover, expanded partnerships can include other service systems and community-providers with whom justice-involved individuals frequently interact, such as mental health, health services, and community corrections. Lastly, states and the federal government and professional organizations can play an important role by supporting the expansion of evidencebased overdose prevention programs to enable criminal justice systems, in conjunction with community-based providers, to incorporate overdose prevention as part of their ongoing services.

\section{Supplementary Information}

The online version contains supplementary material available at https://doi. org/10.1186/s13011-021-00346-1.

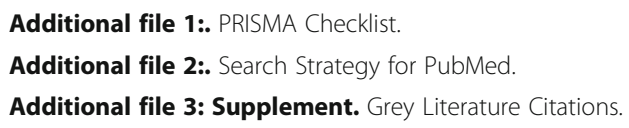

\section{Abbreviations}

AOR: Adjusted odds ratio; Cl: Confidence interval; CJS: Criminal justice system; DRD: Drug-related death; ED: Emergency department; EMS: Emergency medical services; HR: Hazard ratio; IDU: Injection drug use; IR: Incidence rate; MAT: Medication-assisted treatment; MOUD: Medications for opioid use disorder; N-ALIVE: NALoxone InVEstigation Study; NESI: Needle Exchange Surveillance Initiative; NFOD: Non-fatal overdose; NNP: National Naloxone Program; OAT: Opiate agonist treatment; OD: Overdose; OEND: Overdose education and naloxone distribution; OR: Odds ratio; ORD: Opioid-related deaths; OST: Opioid substitution treatment; OUD: Opioid use disorder; PWID: People who inject drugs; RCT: Randomized controlled trial; SMR: Standardized mortality ratio; SUD: Substance use disorder; THN: Take-home naloxone

\section{Acknowledgements}

The authors thank Kelli Wright for her assistance in manuscript prepration.

\section{Authors' contributions}

CEG: Led development of study conceptualization, co-led coding and analysis of articles, led writing of manuscript. EO: Conducted literature search, prepared review documentation, co-led coding and analysis of articles, contributed to writing manuscript. CKS: Funding acquisition, conceptual development of study, reviewed the manuscript, and provided critical content. MLD: Funding acquisition, conceptual development of study, reviewed the manuscript, and provided critical content. JC: Reviewed the manuscript and provided critical content. DPW: Reviewed the manuscript and provided critical content. The author(s) read and approved the final manuscript.

\section{Funding}

This study is supported by U01 DA036221 (Dennis, Scott) Supplement to Juvenile Justice Translational Research on Interventions for Adolescents in the Legal Systems (JJ-TRIALS): Coordinating Center to Reduce Substance Use, HIV Risk Behaviors, and Crime. The paper's contents are solely the responsibility of the authors and do not necessarily represent the official views of the funding organization.
Availability of data and materials

Data sharing is not applicable to this article as no datasets were generated or analyzed during the current study.

Ethics approval and consent to participate

This study was an analysis of preexisting literature and did not use human subjects.

Consent for publication

Not applicable.

\section{Competing interests}

The authors declare they have no competing interests.

\section{Author details}

${ }^{1}$ Chestnut Health Systems, 221 W. Walton St, Chicago, IL 60610, USA.

${ }^{2}$ Carnevale Associates LLC, 4 Belinder Rd, Gaithersburg, MD 20878, USA.

${ }^{3}$ Chestnut Health Systems, 448 Wylie Dr, Normal, IL 61761, USA.

Accepted: 13 January 2021

Published online: 22 February 2021

\section{References}

1. Substance Abuse and Mental Health Services Administration, Center for Behavioral Health Statistics and Quality. National Survey on Drug Use and Health, 2016. Ann Arbor: Inter-university Consortium for Political and Social Research; 2017. http://datafiles.samhsa.gov/study-dataset/national-surveydrug-use-and-health-2016-nsduh-2016-ds0001-nid17185. Accessed 24 Sep 2020

2. Winkelman T, Chamg WW, Binswanger IA. Health, polysubstance use, and criminal justice involvement among adults with varying levels of opioid use. JAMA Netw Open. 2018;1(3):e180558.

3. Borschmann R, Tibble H, Spittal MJ, Pirkis J, Preen D, Larney S, et al. The Mortality After Release from Incarceration Consortium (MARIC): Protocol for a multi-national, individual participant data meta-analysis. Int J Popul Data Sci. 2019;5(1):06.

4. McDonald R, Campbell ND, Strang J. Twenty years of take-home naloxone for the prevention of overdose deaths from heroin and other opioids_conception and maturation. Drug Alcohol Depend. 2017;178:17687.

5. Clark AK, Wilder CM, Winstanley EL. A systematic review of community opioid overdose prevention and naloxone distribution programs. J Addict Med. 2014;8(3):153-63.

6. McDonald R, Strang J. Are take-home naloxone programmes effective? Systematic review utilizing application of the Bradford Hill criteria. Addict. 2016;111(7):1177-87.

7. Naumann RB, Durrance CP, Ranapurwala SI, Austin AE, Proscholdbell S, Childs $R$, et al. Impact of a community-based naloxone distribution program on opioid overdose death rates. Drug Alcohol Depend. 2019;204:107536.

8. Tricco AC, Lillie E, Zarin W, O'Brien KK, Colguhoun H, Levac D, et al. PRISMA extension for scoping review (PRISMA-SCR): checklist and explanation. Ann Intern Med. 2018;169(7):467-73.

9. Liberati A, Altman DG, Tetzlaff J, Mulrow C, Gøtzsche PC, loannidis JP, et al. The PRISMA statement for reporting systematic reviews and meta-analyses of studies that evaluate health care interventions: explanation and elaboration. PLoS Med. 2009:6(7):e1000100.

10. Moher D, Liberati A, Tetzlaff J, Altman DG, Group P. Preferred reporting items for systematic reviews and meta-analyses: the PRISMA statement. PLoS Med. 2009;6(7):e1000097.

11. Hedegaard H, Miniño AM, Warner M. Drug overdose deaths in the United States, 1999-2018. NCHS Data Brief, no 356. Hyattsville: National Center for Health Statistics; 2020.

12. Horton M, McDonald R, Green TC, Nielsen S, Strang J, Degenhardt L, et al. A mapping review of take-home naloxone for people released from correctional settings. Int J Drug Policy. 2017;46:7-16.

13. Charmaz K. Constructing grounded theory: a practical guide through qualitative analysis. Thousand Oaks: Sage; 2006.

14. Bennett T, Holloway K. The impact of take-home naloxone distribution and training on opiate overdose knowledge and response: an evaluation of the THN project in Wales. Drugs (Abingdon Engl). 2012;19(4):320-8. 
15. Cropsey KL, Martin S, Clark CB, McCullumsmith CB, Lane PS, Hardy S, et al. Characterization of opioid overdose and response in a high-risk community corrections sample: a preliminary study. J Opioid Manag. 2013;9(6):393-400.

16. Curtis M, Dietze P, Aitken C, Kirwan A, Kinner SA, Butler T, et al. Acceptability of prison-based take-home naloxone programmes among a cohort of incarcerated men with a history of regular injecting drug use. Harm Reduct J. 2018;15(1):48.

17. Davidson PJ, Wagner KD, Tokar PL, Scholar S. Documenting need for naloxone distribution in the Los Angeles County jail system. Addict Behav. 2019;92:20-3.

18. Gicquelais RE, Mezuk B, Foxman B, Thomas L, Bohnert ASB. Justice involvement patterns, overdose experiences, and naloxone knowledge among men and women in criminal justice diversion addiction treatment. Harm Reduct J. 2019;1(16):46.

19. Holloway K, Hills R, May T. Fatal and non-fatal overdose among opiate users in South Wales: a qualitative study of peer responses. Int J Drug Policy. 2018;56:56-63.

20. Koester S, Mueller SR, Raville L, Langegger S, Binswanger IA. Why are some people who have received overdose education and naloxone reticent to call emergency medical services in the event of overdose? Int J Drug Policy. 2017:48:115-24.

21. Petterson AG, Madah-Amiri D. Overdose prevention training with naloxone distribution in a prison in Oslo, Norway: a preliminary study. Harm Reduct J. 2017;14:74.

22. Barocas JA, Baker L, Hull SJ, Stokes S, Westergaard RP. High uptake of naloxone-based overdose prevention training among previously incarcerated syringe-exchange program participants. Drug Alcohol Depend. 2015;154:283-6.

23. Bird SM, McAuley A, Munro A, Hutchinson SJ, Taylor A. Prison-based prescriptions aid Scotland's National Naloxone Programme. Lancet. 2017; 389(10073):1005-6.

24. McAuley A, Munro A, Bird SM, Hutchinson SJ, Goldberg DJ, Taylor A Engagement in a National Naloxone Programme among people who inject drugs. Drug Alcohol Depend. 2016;162:236-40.

25. O'Hallaran C, Cullen K, Njoroge J, Jessop L, Smith J, Hope V, et al. The extent of and factors associated with self-reported overdose and self-reported receipt of naloxone among people who inject drugs (PWID) in England, Wales and Northern Ireland. Int J Drug Policy. 2017;46:34-40.

26. Bird SM, McAuley A. Scotland's national naloxone programme. Lancet. 2019; 393(10169):316-7.

27. Bird SM, McAuley A, Perry S, Hunter C. Effectiveness of Scotland's National Naloxone Programme for reducing opioid-related deaths: A before (200610) versus after (2011-13) comparison. Addict. 2016;111:883-91.

28. Green TC, Ray M, Bowman SE, McKenzie M, Rich JD. Two cases of intranasal naloxone self-administration in opioid overdose. Subst Abus. 2014;35(2): 129-32.

29. Huxley-Reicher Z, Maldjian L, Winkelstein E, Siegler A, Paone D, Tuazon E, et al. Witnessed overdoses and naloxone use among visitors to Rikers Island jails trained in overdose rescue. Addict Behav. 2018;86:72-8.

30. Kobayashi L, Green TC, Bowman SE, Ray MC, McKenzie MS, Rich JD. Patient simulation for assessment of layperson management of opioid overdose with intranasal naloxone in a recently-released prisoner cohort. Simul Healthc. 2017;12:22-7.

31. Parmar MKB, Strang J, Choo L, Meade AM, Bird SM. Randomized controlled pilot trial of naloxone-on-release to prevent post-prison opioid overdose deaths. Addict. 2017;112:502-15.

32. Wenger LD, Showalter D, Lambdin B, Leiva D, Wheeler E, Davidson PJ, et al. Overdose education and naloxone distribution in the San Francisco County Jail. J Correct Health Care. 2019;4(25):394-404.

33. Green TC, Bowman SE, Ray M, McKenzie M, Lord SE, Rich JD. Development of an incarceration-specific overdose prevention video: staying Alive on the outside. Health Educ J. 2015:75(5):627-37.

34. Horsburgh K, McAuley A. Scotland's national naloxone program: the prison experience. Drug Alcohol Rev. 2018;37(4):454-6.

35. Pearce LA, Mathany L, Rothon D, Kuo M, Buxton JA. An evaluation of take home naloxone program implementation in British Columbian correctional facilities. Int J Prison Health. 2019;1(15):46-57.

36. Sondhi A, Ryan G, Day E. Stakeholder perceptions and operational barriers in the training and distribution of take-home naloxone within prisons in England. Int J Drug Policy. 2016;13:5.
37. Zucker H, Annucci AJ, Stancliff S, Catania H. Overdose prevention for prisoners in New York: a novel program and collaboration. Harm Reduct J. 2015;12:51.

38. Alex B, Weiss DB, Kaba F, Rosner Z, Lee D, Lim S, et al. Death after jail release: Matching to improve care delivery. J Correct Health Care. 2017; 23(1):83-7.

39. Andersson L, Håkansson A, Krantz P, Johnson B. Investigating opioid-related fatalities in southern Sweden: Contact with care-providing authorities and comparison of substances. Harm Reduct J. 2020;1(17):5.

40. Binswanger IA, Nowels C, Corsi KF, Glanz J, Long J, Booth RE, et al. Return to drug use and overdose after release from prison: a qualitative study of risk and protective factors. Addict Sci Clin Pract. 2012;7:3.

41. Binswanger IA, Stern MF, Yamashita TE, Mueller SR, Baggett TP, Blatchford PJ. Clinical risk factors for death after release from prison in Washington State: A nested case-control study. Addict. 2016:111:499-510.

42. Binswanger IA, Nguyen AP, Morenoff JD, Xu S, Harding DJ. The association of criminal justice supervision setting with overdose mortality: a longitudinal cohort study. Addict. 2020; https://doi.org/10.1111/add.15077.

43. Bird SM, Fischbacher CM, Graham L, Fraser A. Impact of opioid substitution therapy for Scotland's prisoners on drug-related deaths soon after prisoner release. Addict. 2015;110:1617-24.

44. Bukten A, Stavseth MR, Skurtveit S, Tverdal A, Strang J, Clausen T. High risk of overdose death following release from prison: variations in mortality during a 15-year observation period. Addict. 2017;112:1432-9.

45. Cepeda J, Vetrova M, Lyubimova Al, Levina OS, Heimer R, Niccolai LM. Community reentry challenges after release from prison among people who inject drugs in St. Petersburg, Russia. Int J Prison Health. 2015;11(3): 183-92.

46. Forsyth SJ, Carroll M, Lennox N, Kinner SA. Incidence and risk factors for mortality after release from prison in Australia: a prospective cohort study. Addict. 2018;113:937-45

47. Hacker K, Jones LD, Brink L, Wilson A, Cherna M, Dalton E, Hulsey EG. Linking opioid-overdose data to human services and criminal justice data: opportunities for intervention. Public Health Rep. 2018;133(6):658-66.

48. Keen C, Young JT, Borschmann R, Kinner SA. Non-fatal drug overdose after release from prison: a prospective data linkage study. Drug Alcohol Depend. 2020;206:107707.

49. Kinner SA, Milloy M-J, Wood E, Qi J, Zhang R, Kerr T. Incidence and risk factors for non-fatal overdose among a cohort of recently incarcerated illicit drug users. Addict Behav. 2012;37:691-6.

50. Larochelle MR, Bernstein R, Bernson D, Land T, Stopka TJ, Rose AJ, et al. Touchpoints - opportunities to predict and prevent opioid overdose: a cohort study. Drug Alcohol Depend. 2019;204:107537.

51. Moore E, Winter R, Indig D, Greenberg D, Kinner SA. Non-fatal overdose among adult prisoners with a history of injecting drug use in two Australian states. Drug Alcohol Depend. 2013;133:45-51.

52. Pizzicato LN, Drake R, Domer-Shank R, Johnson CC, Viner KM. Beyond the walls: risk factors for overdose mortality following release from the Philadelphia Department of Prisons. Drug Alcohol Depend. 2018;189:108-15.

53. Ranapurwala SI, Shanahan ME, Alexandridis AA, Proescholdbell SK, Naumann RB, Edwards D, et al. Opioid overdose mortality among former North Carolina inmates: 2000-2015. Am J Public Health. 2018; 109(9):1207-13.

54. Spittal MJ, Forsyth S, Borschmann R, Young JT, Kinner SA. Modifiable risk factors for external cause mortality after release from prison: a nested casecontrol study. Epidemiol Psychiatr Sci. 2019;2(28):224-33.

55. Wagner KD, Liu L, Davidson PJ, Cuevas-Mota J, Armenta RF, Garfein RS. Association between non-fatal opioid overdose and encounters with healthcare and criminal justice systems: identifying opportunities for intervention. Drug Alcohol Depend. 2015;153:215-20.

56. Winter RJ, Stoové M, Degenhardt L, Hellard ME, Spelman T, Jenkinson R, et al. Incidence and predictors of non-fatal drug overdose after release from prison among people who inject drugs in Queensland, Australia. Drug Alcohol Depend. 2015;153:43-9.

57. Bird SM, Parmar MKB, Strang J. Take-home naloxone to prevent fatalities from opiate-overdose: protocol for Scotland's public health policy evaluation, and a new measure to assess impact. Drugs Educ Prev Policy. 2015;22:66-76.

58. Bagley SM, Schoenberger SF, Waye FM, Walley AY. A scoping review of post opioid-overdose interventions. Prev Med. 2019:128:105813. 
59. Ambrose G, Amlani A, Buxton JA. Predictors of seeking emergency medical help during overdose events in a provincial naloxone distribution programme: a retrospective analysis. BMJ Open. 2016;6:e011224.

60. Watson DP, Ray B, Robison L, Huynh P, Sightes E, Brucker K, et al. Lay responder naloxone access and good Samaritan law compliance: postcard survey results from 20 Indiana counties. Harm Reduct J. 2018;15(1):18.

61. Belenko S, Hiller M, Hamilton L. Treating substance use disorders in the criminal justice system. Curr Psychiatry Rep. 2013;15(11):414.

62. Friedmann PD, Hoskinson R, Godon M, Schwartz R, Kinlock T, Knight K, et al. Medication-assisted treatment in criminal justice agencies affiliated with the criminal justice-drug Abuse treatment studies (CJ-DATS): availability, barriers \& intentions. Subst Abus. 2012;33(1):9-18.

63. Mitchell SG, Willet J, Monico LB, James A, Rudes DS, Viglione J, et al, Community correctional agents' views of medication-assisted treatment: examining their influence on treatment referrals and community supervision practices. Subst Abus. 2016;37(1):127-33.

64. Burris S, Blankenship KM, Donoghoe M, Sherman S, Vernick JS, Case P, et al. Addressing the "risk environment" for injection drug users: the mysterious case of the missing cop. Milbank Q. 2004;82(1):125-56.

65. Cooper HLF, Bossak B, Tempalski B, Des Jarlais DC, Friedman SR. Geographic approaches to quantifying the risk environment: drug-related law enforcement and access to syringe exchange programmes. Int J Drug Policy. 2009;20:217-26

66. Rhodes T. The 'risk environment': a framework for understanding and reducing drug-related harm. Int J Drug Policy. 2002;13:85-94.

67. Grant MJ, Booth A. A typology of reviews: an analysis of 14 review types and associated methodologies. Health Inf Libr J. 2009;26(2):91-108.

68. Levac D, Colquhoun H, O'Brien KK. Scoping studies: advancing the methodology. Implement Sci. 2010;5:1-9.

69. Friedmann PD, Wilson D, Knudsen HK, Ducharme L, Welsh WN, Frisman L, et al. Effect of an organizational linkage intervention on staff perceptions of medication-assisted treatment and referral intentions in community corrections. J Subst Abus Treat. 2015:50:50-8.

70. Welsh WN, Knudsen HK, Knight K, Ducharme L, Pankow J, Urbine T, et al. Effects of an organizational linkage intervention on inter-organizational service coordination between probation/parole agencies and community treatment providers. Admin Pol Ment Health. 2016;43:105-21.

\section{Publisher's Note}

Springer Nature remains neutral with regard to jurisdictional claims in published maps and institutional affiliations.

Ready to submit your research? Choose BMC and benefit from:

- fast, convenient online submission

- thorough peer review by experienced researchers in your field

- rapid publication on acceptance

- support for research data, including large and complex data types

- gold Open Access which fosters wider collaboration and increased citations

- maximum visibility for your research: over $100 \mathrm{M}$ website views per year

At $\mathrm{BMC}$, research is always in progress.

Learn more biomedcentral.com/submissions 